\title{
ELETRICITY CONSUMPTION OF HOUSEHOLD -A CASE STUDY OF THIRUVANANTHAPURAM CORPORATION
}

\author{
Dr. SMITHA V P \\ Assistant Professor in Economics, HHMSPB NSS College for Women, Neeramankara \\ DOI: 10.46609/IJSSER.2021.v06i07.002 URL: https://doi.org/10.46609/IJSSER.2021.v06i07.002
}

\begin{abstract}
India is one of the most populated countries in the world so its energy consumption is also high. Renewable and non- renewable sources of energy are two important sources of consuming energy. But the use of non-renewable sources of energy creates several environmental and economic harmful effects in the economy. Along with this, non-renewable sources are limited in its supply. Besides, there are not enough other alternative sources of energy in our economy. Therefore the study of renewable sources of energy is important for the current situation prevails in the economy. Renewable sources of energy gave the advantages like it ensure stable prices, maintain low cost, create more employment opportunity, provide cleaner environment, reduce deforestation protect the wildlife and so on. It is in the context that the study relating to renewable resources is being undertaken. The electricity consumption has increased day by day. Most of the families in the Thiruvananthapuram Corporation are nuclear families. At least one member of the family is employed. More members of people work in private sectors and government sectors.
\end{abstract}

Keywords: Fossil Fuels, Renewable Energy, Wave Energy

\section{Introduction}

The most important single factor which can act as a constraint on economic growth of a country is the availability of energy. India is both a major energy producer and consumer. Currently, India ranks as the world's third largest energy producer and energy consumer. Continuously rising demand combined with increasingly limited natural resources are challenging energy suppliers for both industries and consumers and force to rethink how we produce and use energy. Renewable energy implies naturally replenished resources. It is obtained from renewable natural resource such as sunlight, wind, rain, tides, and geothermal heat. About $16 \%$ of the global final energy consumption comes from renewable, with $10 \%$ coming from traditional biomass, which is mainly used for heating, and 3.45 from hydroelectricity. New renewable (small hydro, modem biomass, wind, solar geothermal and 


\section{International Journal of Social Science and Economic Research}

ISSN: $2455-8834$

Volume:06, Issue:07 "July 2021"

bio fuels) accounted for another 3\% and are growing very rapidly. The share renewable in electricity generation is around 19\%, with $16 \%$ of global electricity coming from hydroelectricity and $3 \%$ from other new renewable.

On the other hand, non-renewable resources are formed from organic carbon material which is formed over the course of billions of years. Non-renewable Resources of energy and physical resources like coal, petroleum and gas are organic in nature and remaining are fossils known as fossil fuels. These resources are often costly to mine, as they are usually deep within the Earth's crust. The burning of fossil fuels has harmful consequences to the environment and contributes to global warming and climate change. For this reason, many organizations have developed alternative energy sources that don't rely on these resources.

In the era of industrial revolution the conventional energy sources such oil, coal, and natural gas have proven to be highly effective drivers of economic progress, but at the sametime emission from such sources have damaged our environment contributing to global warming and consequent climate change. The Inter-governmental Panel on Climate Change (1PCC) has been discussing and raising the issue of containing emission from fossil fuels and other sources through available scientific and technological options to mitigate the problems of climate change due to gaseous emission and rising $\mathrm{CO} 2$ levels on account of an oil and coal powered global economy. Use of carbon sequestration measures and clean and green renewable energy has been persistently suggested.

Besides the environmental impact of burning fossil fuels, the economic impact of non-renewable resources can also be damaging. Following the basic premise of supply and demand, Supply of many of these fuels is in danger of running out completely. Eventually, the price will hit a point that end users cannot afford, forcing a move toward alternative energy sources. The alternative to using non-renewable resources is to use renewable resources, including such sources as solar and wind power or any source that is essentially unlimited in supply or reusable

Renewable energy sources derive their energy from existing flows of energy from ongoing natural processes, such as sun shine, winds, flowing water, biological processes and geothermal heat flows. Renewable energy can be regarded as one of the fundamental premises for building a sustainable global society. The term renewable energy should not be confused with alternative energy, which describes sources of energy, outside the regular forms like gas line that are considered more environment friendly or less harmful. Renewable energy technologies turn these flows into usable forms of energy - most often electricity. But also heat, chemicals or mechanical power. Renewable energy will also help us develop energy independence and security.

\section{Indian Scenario}


International Journal of Social Science and Economic Research

ISSN: 2455-8834

Volume:06, Issue:07 "July 2021"

India has a vast supply of renewable energy resources, and it has one of the largest programs in the world for developing renewable energy products and systems. Indeed, it is the only country in the world to have an exclusive ministry for renewable energy development, The Ministry of NonConventional Energy Sources (NINES). Since it is formation, the ministry has launched one of the world's largest and most ambitious programs on renewable energy. In October, MNES was renamed the Ministry of New and Renewable Energy.

India is the world's third largest producer and third largest consumer of electricity. The national electric grid in India has an installed capacity of 370. $106 \mathrm{GW}$ as of 31 March 2020. Renewable power plants, which also include large hydroelectric plants, constitute $35.86 \%$ of India's total installed capacity.

The key drives of renewable energy are the following

- $\quad$ The demand- supply gap, especially as population increases

- $\quad$ A large untapped potential.

- Concern for the environment

- The need to strengthen India's energy security

- Pressure in high - emission industries sectors from their share holders

- Available solution for rural electrification

\section{Kerala Scenario}

Kerala is one of the states in India blessed with renewable energy resources. Kerala is among the prominent state to have achieved $100 \%$ rural electrification. The state had a total installed power generation capacity of 4,990.81 MW, of which 2,186.48 MW was accounted for by state utilities, 1,829.76 MW by central utilizes and 974.57 MW under private sector. Kerala generates power from four sources-hydro power, thermal power, wind power and solar power. Of these, hydro and thermal power generations make only marginal additions. Monsoon is essential to sustain the hydropower base in the state and the shortage in rainfall usually creates a power crisis.

The beginning of the electricity generation in Kerala was marked in the year 1940 under the Department of Electricity, at Pallivassal. The hydroelectric project with an installed capacity of 37.5 MW was first of its kind in Kerala. With another 8 more hydroelectric projects including the Sabarigiri project (1966), with an installed capacity of 300MW and the Idukki stage 1 (1976), with an installed capacity of $390 \mathrm{MW}$. With the commissioning of more hydroelectric projects, Kerala achieved the status of a power surplus state, which lasted till the late 1980's. The period of surplus between 1969 and 1985 enabled Kerala to sell power to the neighbouring states at very cheap rates. But the late 1980s there occurred a power deficiency in the state. 
International Journal of Social Science and Economic Research

ISSN: 2455-8834

Volume:06, Issue:07 "July 2021"

According to a report published by WWF- India and world Institute of sustainable Energy, the state of Kerala can meet over $95 \%$ of its energy demand with renewable sources by 2050 . This specific report (The Energy Report Kerala) provides a vision for a $100 \%$ renewable and sustainable energy supply by 2050 in Kerala

\section{Relevant Of The Study}

India is one of the most populated countries in the world so its energy consumption is also high. Renewable and non- renewable sources of energy are two important sources of consuming energy. But the use of non-renewable sources of energy creates several environmental and economic harmful effects in the economy. Along with this, non-renewable sources are limited in its supply. Besides, there are not enough other alternative sources of energy in our economy. Therefore the study of renewable sources of energy is important for the current situation prevails in the economy. Renewable sources of energy gave the advantages like it ensure stable prices, maintain low cost, create more employment opportunity, provide cleaner environment, reduce deforestation protect the wildlife and so on. It is in the context that the study relating to renewable resources is being undertaken.

\section{OBJECTIVES}

1. To examine the electricity consumed and the proportion of income spend on electricity bill by the household.

2. How lockdown affect the consumption of electricity.

3. To find out the ways of saving and wastage of electricity in household.

\section{METHODOLOGY}

The study carried out by using both primary and secondary data. The primary data is collected from Kerala State Electricity Board (KSEB) office and by conducting a sample survey among households of Trivandrum co-operation. The secondary data collected was from various publication, internet and data from government of India website. A wide reading from similar topic also helped in the preparation this study.

\section{TOOLS OF ANALYSIS}

The collected data was analysed with the help of percentages and averages. And the tables, graphs and diagrams are used as description techniques.

\section{REVIEW OF RELATED STUDIES}


International Journal of Social Science and Economic Research

ISSN: 2455-8834

Volume:06, Issue:07 "July 2021"

Gupta (2007) has reported in this article that improving access to electricity improves the living standards in rural India and gives an opportunity for socio economic development. Rural electrification is possible by formulating right policies and permitting stand-alone systems based on renewable sources of energy. Hence, power producers that use renewable sources of energy should be given interest subsides as their project coast are front loaded whereas operation coast are almost negligible. Also, privet ownership will result in good service standards, efficiency, competition, etc. According to UNDP and World Bank estimates on investigations in 15 LCDs. Household energy consumption accounts for 30-95\% compared with 25-30\% in development countries. Ouedraogo (2006) for Africa, Rao \& Reddy (2007) and Pachuari (2004) for India states that the inertia of the household energy preferences and consumption pattern are due to some factors such as economic condition household size, age distribution of the household members, age of holdings, nature of the occupations, low living standard, education attainment of the principal wage earner and of the family members and high frequency of cooking certain meals.

Liming and Huang (2009) realized the importance of financing need for the renewable energy generation in India. They classified the financial system in to several categories such as financing by the government, international funding, commercial and non-commercial bank financing, public stock markets, private sector financing venture capitals, subsidies etc.

Arora (2010) discuss about the significance of renewable energy on the growth of Indian economy. India needs to focus on the energy challenge which will impact all citizens and across all sectors. Currently, the quality of electricity supply is impending and issues like voltage fluctuations, blackouts and various other disruptions impact the commercial and residential consumer. Adding of grid-tied renewable energy can bridge this gap. It provides buffer against energy security concern and can bring hedge against fossil fuels and price hikes. It will support in climate change goals.

Arvizu and Balaya (2012) in their study, says that of all renewable sources of energy if used in best of its potential will impact the environment. It is stated that if direct solar energy is the most abundant of all and also provide opportunities for positive social impact. Over the last 30 years, there has been cost reduction in solar technology and hence potential deployment scenario for solar energy to become one of the major source of energy supply by 2050 .

Sinha and Joshi (2012) state that the status of solar PV research in India in relation to its aspect pattern of output, impact of research, etc. It focuses on comprehensive mapping of solar PVR \& D capability of India that should be taken on priority bases to make effective strategies to take advantage of supportive policies of govt. Even being the first country in the world to have 


\section{International Journal of Social Science and Economic Research}

ISSN: $2455-8834$

Volume:06, Issue:07 "July 2021"

dedicated ministry of renewable energy. India still lags far behind in solar energy technology competence, generation and utilization.

Muhammad Abul Foysal (2012) made a case study on "Household consumption pattern areas of Bangladesh". They explained that energy is the important determinant of the quality of life in human settlements. They have explained revealed that households use fire wood, cow dung, leaves and twigs, branches, straw and rice husk as bio mass energy mainly for cooking is $98.3 \%$. This study is helpful to formulate policies support tools to take into account the future challenges for demand fuel resources, their sustainable utilization, promotion and development.

National Productivity Council (NPC) energy management group state wise electricity consumption and conservation potential in India for Bureau of Energy Efficiency (BEE) ministry of power, government of India conduct a study. This study focused only on estimation of the total electricity consumption and saving potential in following sectors of each state. They area agricultural pumping, Municipal water and sewage pumping street light, commercial building like hotel, hospitals, shopping, office, public park having connected load of more than 500kw. The domestics sector electricity consumption varies with respect to rural and urban segments and climatic seasonal variations.

Srivastava Swami \& Shrivastava Survat (2013) found that electricity is one of the core components in industrial growth \& economic progress. India being one of the most populated countries is now facing acute energy scarcity. The time has come for the country to think on utilization of abundant of renewable energy resources such as solar energy. It is one of the prime renewable energy source. There are few challenges \& constraints with regards to the solar energy power system such as land scarcity, slow progress. Govt. support and so on. However, the Jawaharlal Nehru National Solar Mission is aiming at development and deployment of solar energy technologies in the country by 2022. Considering other facts such as economic growth, rural electrification abundant source of energy solar power is economically viable. Thus, there is a lot of scope in positioning solar energy devices in rural \& urban areas of Pune region.

Asinda. S (2013) state that there is no such product in the world which does not hold any position. Especially in such a market where there is intensive rivalry and competition. Buyers have number of choices. To know that consumers want and position the product in their minds as per the perception has become critical. It can be concluded that marketing, positioning and its strategy are closely related. It involves creating uniqueness, consistency and a competitive weightage in the market.

Kumar. A (2013) has been observed that India has huge potential of being one of the leading nations in usage of renewable source of energy. Solar energy shares 13\% availability in India. An efficient energy management can help in optimum utilization of potentials of renewable 


\section{International Journal of Social Science and Economic Research}

ISSN: $2455-8834$

Volume:06, Issue:07 "July 2021"

sources. After considering these facts, it can be concluded that economic growth of any country depends in the long term availability of energy from sources that are affordable, accessible and secured.

Rajkumar and Balasubramaniam (2013) Author has observed that India has huge potential of being one of the leading nations in usage of renewable source of energy. Solar energy shares $13 \%$ availability of all the renewable sources available in India. An efficient energy management can help in optimum utilization of the potentials of renewable sources. Having an exclusive Ministry of Non-conventional Energy Source (MNES) is an advantage for India, which will bring reforms to put in place the resources for renewable energy development.

Burogohain (2013) Author has summarized that rural electrification through solar devices has huge impact on the living standards of villagers. It gives them safety and security over kerosene lamps with an economic advantage, light for children to study, hence boasting child education, reduction in crime rates due to availability of lights in village surroundings, etc.

Panwar. V \& Kaur. T (2014) Authors have studied renewable energy resources of India and its importance to generate power in near future. From this literature it can be concluded that the sun provides 1000 times more power than we need. If we can use $5 \%$ of this energy, it will be 50 times what world required. Solar thermal principles can be used to produce electricity can be a great option of replacement to fossil based energy system.

Ahmed. A, Khalid. S, Qussain. S, and Tiwari. G (2014) the development of renewable energy source is an alternate to achieve the challenge of sustainable energy development. At present $87 \%$ of power is generated through conventional sources in India. Most parts of India have approx. 300 clear sunny days in a year. This solar energy is either utilized by solar thermal power system or solar photovoltaic. Hence it can be concluded that solar energy source can take sources which will lead towards the exploration and development of technologies for power generation from renewable resources.

Thilagavathi and Mownica (2014) states that solar power is emerging as one of the best alternative to electricity. It comes up the clean green electricity. Its various applications have become saviors to power cuts, lower availability of grid electricity, etc. Solar water heater has eloped as the most popular device that reduces electricity consumption to more than $30 \%$. Study has evaluated the customer satisfaction and factors influencing customer sot purchase these products, etc. It focuses on customer's needs and wants and hence, manufactures can achieve customer satisfaction by giving more user friendly, innovative and cost effective products.

Brown (2015) has stated that the risk of extinction fossil fuels and climate instability is being replaced by wind, solar and geothermal energy alternatives and revolutionizing the global energy platform. Energy investors are focusing on utility-scale solar projections. 
According to the National Sample Survey Office (NSSO)'s surveys, (2017) about 20\% of electrified households consume less than 30 units of electricity per month, while about $80 \%$ consume less than 100 units per month. In rural areas, 90\% of the electrified households consume less than 100 units. This distribution varies with states. In most states, about 15-20\% of all the households consume less than 30 units per month. The states consuming the least electricity are Karnataka, West Bengal, Bihar and Jharkhand.

\section{ELECTRICITY CONSUMPTION- AN OVERVIEW}

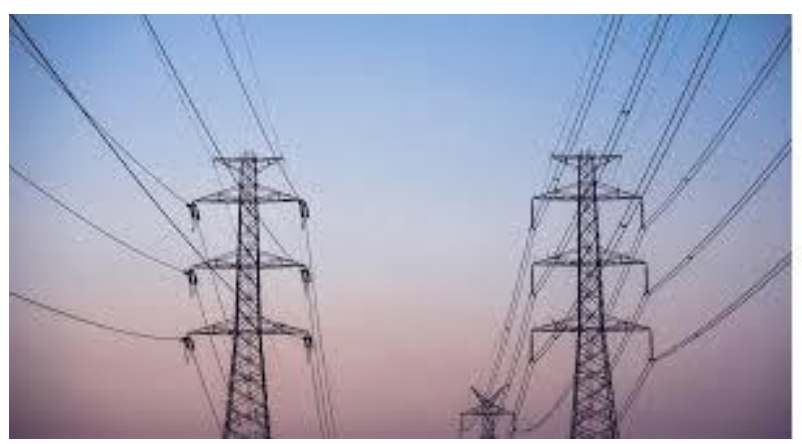

Fig: 3.1

Electricity is one of the most important blessings that science give as mankind. It is an essential part of modern life and important to every economy. It is become a part of our daily life and one cannot think of a world without electricity. People use electricity for lighting, heating, cooling, operating appliances, computer, electronics, machinery, and public transportation system. All these provide comfort to people. Electricity is easy use and move from one location to another. It is weightless so it easier to transport and distribute, but it is almost impossible to store in any large quantity. Electricity is used by industries, households, and businesses.

Modern means of transportation and communication have been revolutionized by it. Electric trains and battery cars are quick means of travel. Electricity also provide means of amusement, radio, television, and cinema, which are the most popular forms of entertainment are the result of electricity. Electricity plays a pivotal role in the field of medicines and surgery too such as X-ray, ECG. The use of electricity is increasing day by day. 


\section{International Journal of Social Science and Economic Research}

ISSN: 2455-8834

Volume:06, Issue:07 "July 2021"

\section{SOLAR ENERGY}

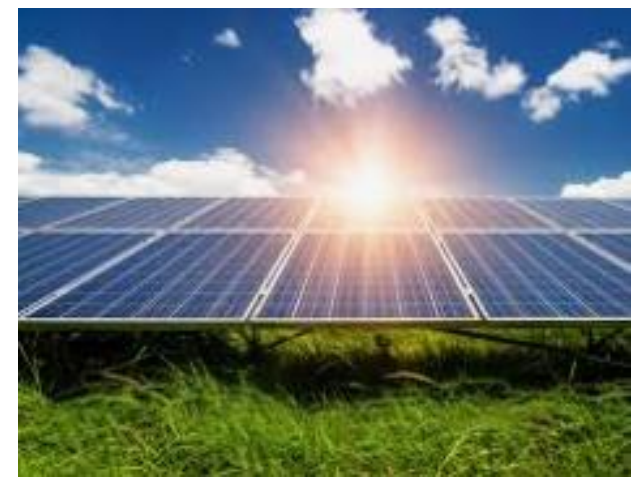

Fig: 3.2

Solar power is one of the best renewable energy sources available because it is one the cleanest source of energy. Solar power is the conversion of sunlight into electricity either directly by using photo voltaic or concentrated solar power. The photo voltaic generation is technique of converting solar radiation or photon energy in to direct current electricity using a semiconductor material that exhibits photo voltaic. The international agency has numerated photo voltaic application in to four categories. O-grid domestic, o-grid nondomestic, grid connected distributed, and grid connected centralized. The dominance of PV among renewable energy technologies is owned mostly to noiselessness, non-toxic emission and relatively simple operation and maintenance. Solar energy falling on the Earths continents is more than 200 times the total annual commercial energy currently being used by humans. Sunlight or solar energy has a variety of features and can be used heating and lighting, generating electricity, hot water, solar cooling across home, commercial property and for industrial use. There are two types of solar energy

- Passive solar energy

- Active solar energy

\section{Passive solar energy}

Passive solar energy is making direct and indirect use of thermal energies from the sun

\section{Active solar energy}

It is the use of the sun's electromagnetic radiation in generating electrical energy 


\section{International Journal of Social Science and Economic Research}

ISSN: 2455-8834

Volume:06, Issue:07 "July 2021"

\section{WIND ENERGY}

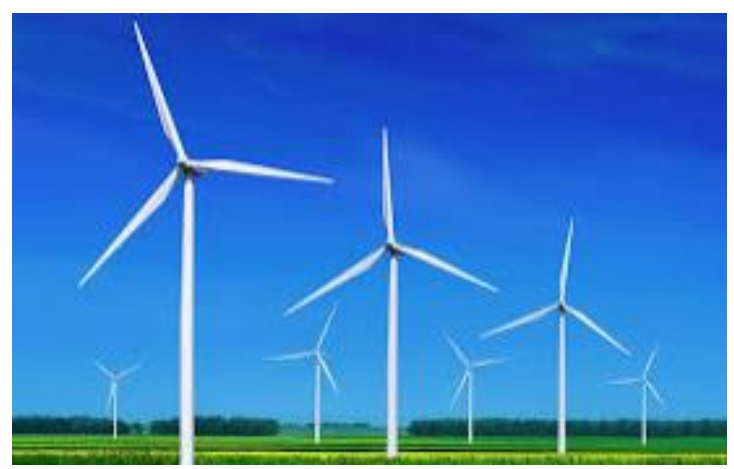

Fig: 3.3

Wind energy one of the most promising alternative energy technologies of the future. Wind energy is a kinetic energy associated with movement of large masses of air. This motion results from uneven heating of the atmosphere by the sun, creating temperature density, and pressure. Wind power is the conversion of wind energy into a useful form of energy. Such as using wind turbines to make electrical power, wind mill for mechanical power, wind pumps for water pumping or drainage, or rail to proper ships.

Wind farms consists of many individual wind turbines, which are connected to the electric power transmission network. Onshore wind is an inexpensive source of electric power, competitive with or in many places cheaper than coal or gas plants. Onshore wind farms also have an impact on the landscape, as typically they need to be spread over more land than other power stations and need to be built in wild and rural areas, which can lead to " industrialization of the countryside" and habitat loss. Offshore wind is steadier and stronger than on land and offshore farms have less visual impact, but construction and maintenance cost are higher. Small onshore wind farms can feed some energy into the grid or provide electric power to isolated off-grid locations. The turbines are manufactured in a wide range of vertical and horizontal axis. The smallest turbans are used for application such as battery charging for auxiliary power for boats or caravans or to power traffic warning signs. Larger turbines can be used for making contributions to a domestic power supply while selling unused power back to the utility supplier via the electrical grid. Arrays of large turbines are known as wind farms, are becoming an increasingly important source of intermittent renewable energy and are used by many countries as part of a strategy to reduce their reliance on fossil fuels.

Wind power is one of the fastest growing renewable energy technologies. Usage is on the rise worldwide, in part because costs are falling. Global installed wind generation capacity onshore and offshore has increased by a factor of almost 75 in the past two decades, jumping from 7.5 gigawatts (GW) in 1997 to some GW by 2018, according to latest data production of wind 
electricity doubled between 2009 and 2013, and in 2016 wind energy accounted for $16 \%$ of the electricity generated by renewables. Many parts of the world have strong wind speed, but the best locations for generating wind power are sometimes remote ones. Offshore wind power offers tremendous potential. A wind turbine or alternatively referred to as a wind energy converter, is a device that converts the wind's kinetic energy in to electrical energy

\section{HYDRO ENERGY}

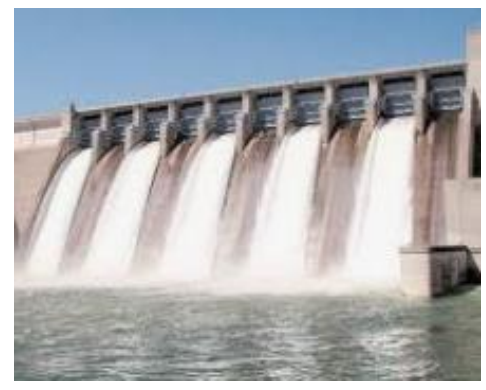

Fig: 3.4

Hydropower or hydroelectricity refers to the conversion of energy from flowing water into electricity. The basic principle of hydropower is using water to drive turbines. Hydropower plants consist of two basic configurations: with dams and reservoirs, or without. Hydropower dams with a large reservoir can store water over short or long periods to meet peak demand. The facilities can also be divided into smaller dams for different purposes, such as night or day use, seasonal storage, or pumped-storage reversible plants, for both pumping and electricity generation. Hydropower without dams and reservoirs means producing at a smaller scale, typically from a facility designed to operate in a river without interfering in its flow. For this reason, many consider small-scale hydro a more environmentally-friendly option.

Historically, one of the first uses of hydro power was for mechanical milling, such as grinding grains. Today, modern hydro plants produce electricity using turbines and generators, where mechanical energy is created when moving water spins rotors on a turbine. This turbine is connected to an electromagnetic generator, which produce electricity when the turbine spins.

There are three main types of hydro plants

- Impoundment facilities are the most common technology which uses a dam to create a large reservoir of water. Electricity is made when water passes through turbines in the dam.

- Pumped storage facilities are similar but have a second reservoir below the dam. Water can be pumped from the lower reservoir to the upper reservoir, storing energy for use at a later time. 
- Run-of-river facilities rely more on natural water flow rates, diverting just a portion of river water through turbines, sometimes without the use of a dam or reservoirs. Since run-of-river hydro is subject to natural water variability, it is more intermittent than dammed hydro.

The advantages of hydropower are many. It is renewable, clean, reliable, flexible and can serve many generations with low-cost electricity from local resources. Hydropower produces no air pollutants and shows the lowest Green House Gases (GHG) emission of all power generation technologies. Worldwide, hydropower accounts for approximately one sixth of the total electricity supply.

\section{GEOTHERMAL ENERGY}

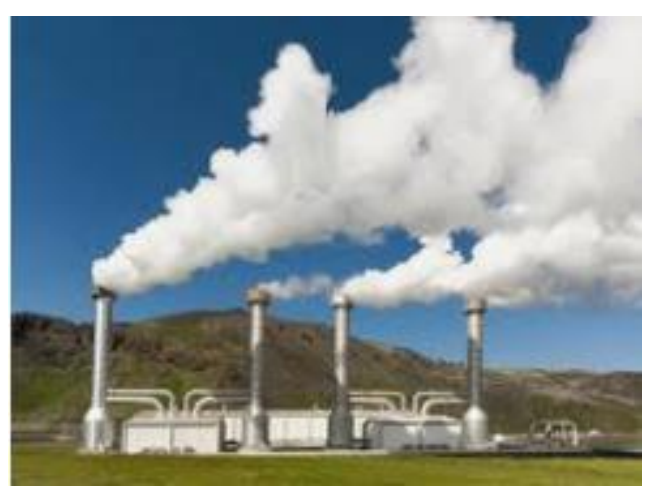

Fig: 3.5

Geothermal energy is a type of geothermal energy taken from the Earth's ones. It comes from heat generated during the original formation of the planet and the radioactive decay of materials. This thermal energy is stored in rocks and fluids in the centre of the earth.

The difference between the temperature in the earth's core and the surface drives a continuous conduction of thermal energy from the centre to the exterior of the planet. High temperatures of over $4000^{\circ} \mathrm{C}$ cause some of the rock in the centre of the Earth to melt and form hot molten rocks called magma. These heats also cause the mantle to behave plastically and portions of it to convert upwards, since it is lighter than the surrounding rock. The rock and water in the Earth's crust can reach heats of around $370^{\circ} \mathrm{C}$. Thermal energy contained in the rocks and fluids can be found from shallow depths right down to several miles below the Earth's surface.

The Earth's geothermal resources are theoretically more than adequate to supply humanity's energy needs, but only a very small fraction may be profitably exploited. Drilling and exploration for deep resources is very expensive. Forecasts for the future of geothermal power 
depend on assumptions about technology, energy prices, subsidies, plate boundary movement and interest rates. Pilot programs like EWEB's customer opt in Green Power Program show that customers would be willing to pay a little more for a renewable energy source like geothermal

\section{BIOMASS ENERGY}

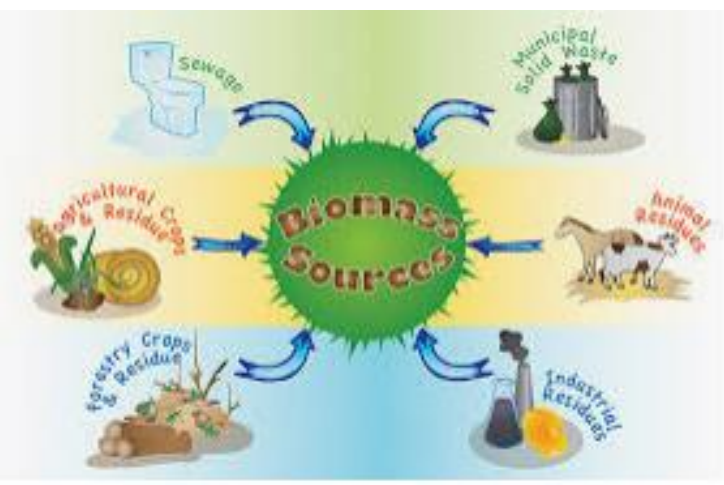

Fig: 3.6

Biomass is a fancy name for material from plants and animals. Some kinds of biomass can be burned to produce energy. One common example is wood. Biomass contains stored energy. That's because plants absorb energy from the sun through the process of photosynthesis. When biomass is burned, this stored energy is released as heat. Burning biomass releases carbon dioxide. However, plants also take carbon dioxide out of the atmosphere and use it to grow their leaves, flowers, branches, and stems. That same carbon dioxide is returned to the air when the plants are burned. Many different kinds of biomass, such as wood chips, corn, and some types of garbage, are used to produce electricity. Some types of biomass can be converted into liquid fuels called biofuels that can power cars, trucks, and tractors. Leftover food products like vegetable oils and animal fats can create biodiesel, while corn, sugarcane, and other plants can be fermented to produce ethanol.

\section{OCEAN ENERGY}

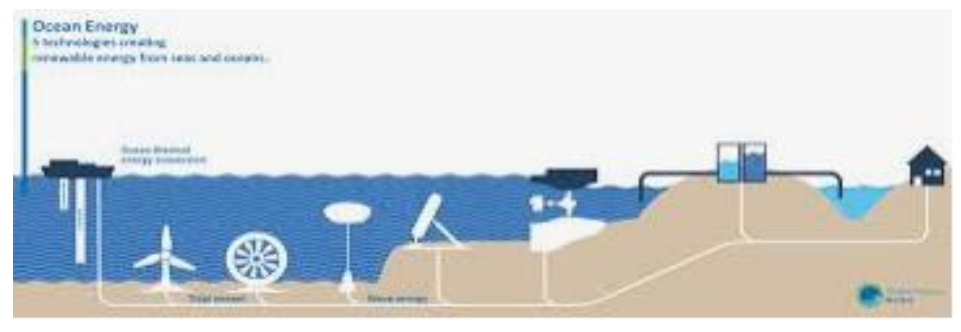

Fig; 3.7 
The ocean forms one of the largest yet least explored renewable energy sources on earth. Ocean energy has the potential for providing a substantial amount of new renewable and reliable energy around the world. Oceans cover more than 70\% of Earth's surface, making them the world's largest solar collectors. The sun's heat warms the surface water a lot more than the deep ocean water, and this temperature difference creates thermal energy. Just a small portion of the heat trapped in the ocean could power the world.

Tides, waves and currents can be used to produce electricity. Although still at the research and development stage and not yet commercially available, promising ocean technologies include:

Wave energy, whereby converters capture the energy contained in ocean waves and use it to generate electricity. Converters include oscillating water columns that trap air pockets to drive a turbine; oscillating body converters that use wave motion; and overtopping converters that make use of height differences.

Tidal energy, produced either by tidal-range technologies using a barrage (a dam or other barrier) to harvest power between high and low tide; tidal-current or tidal-stream technologies; or hybrid applications.

Salinity gradient energy, arising from differing salt concentrations, as occurs where a river empties into an ocean. Demonstration projects use "pressure retarded osmosis", with freshwater flowing through a membrane to increase the pressure in a tank of saltwater; and "reverse electro dialysis" with ions of salt passing through alternating tanks of salt- and freshwater.

Ocean thermal energy conversion, which generates power from the temperature difference between warm surface seawater and cold seawater at 800-1,000 metres depth.

\section{Non-renewable energy}

A non-renewable resource is also known as finite resources. It is a natural resource that cannot be readily replaced by natural means at a quick enough pace to keep up with consumption. An example is carbon-based fossil fuel. The original organic matter, with the aid of heat and pressure, becomes a fuel such as oil or gas. Each minerals and metal ores, fossil fuels (coal, petroleum, natural gas) and groundwater in certain aquifers are all considered non-renewable resources, though individual elements are always conserved

Non- renewable resources mainly in 2 types

- Fossil fuels

- Nuclear fuels 


\section{International Journal of Social Science and Economic Research}

ISSN: 2455-8834

Volume:06, Issue:07 "July 2021"

\section{FOSSIL FUELS}

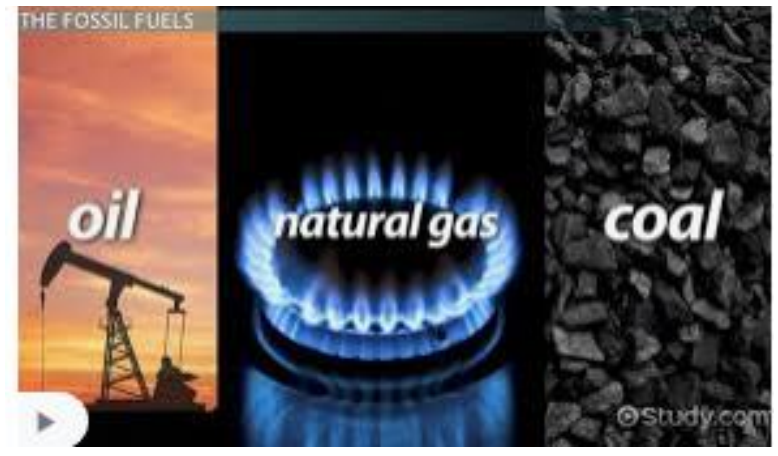

fig: 3.8

Natural resources such as coal, petroleum (crude oil) and natural gas take thousands of years to form naturally and cannot be replaced as fast as they are being consumed. Eventually it is considered that fossil-based resources will become too costly to harvest and humanity will need to shift its reliance to other sources of energy such as solar or wind power, see renewable resources.

An alternative hypothesis is that carbon based fuel is virtually inexhaustible in human terms, if one includes all sources of carbon-based energy such as methane hydrates on the sea floor, which are vastly greater than all other carbon based fossil fuel resources combined. These sources of carbon are also considered non-renewable, although their rate of formation/replenishment on the sea floor is not known. However their extraction at economically viable costs and rates has yet to be determined.

At present, the main energy source used by humans is non-renewable fossil fuels. Since the dawn of internal combustion engine technologies in the 19th century, petroleum and other fossil fuels have remained in continual demand. As a result, conventional infrastructure and transport systems, which are fitted to combustion engines, remain prominent throughout the globe. The modern-day fossil fuel economy is widely criticized for its lack of renewability, as well as being a contributor to climate change. 


\section{International Journal of Social Science and Economic Research}

ISSN: 2455-8834

Volume:06, Issue:07 "July 2021"

\section{NUCLEAR POWER}

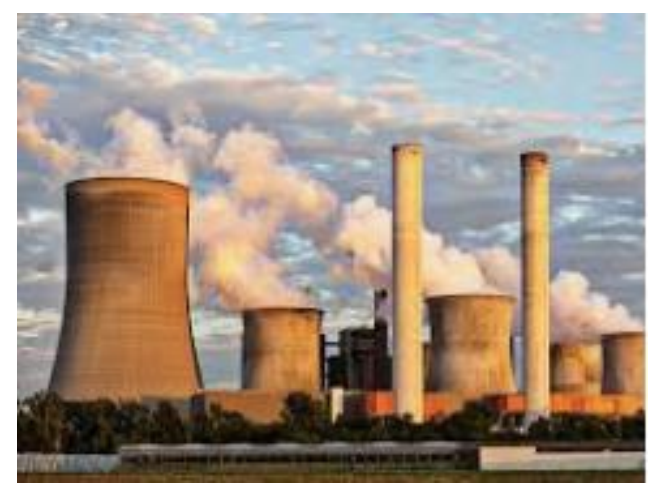

Fig: 3.9

Nuclear power is the use of nuclear reaction that release nuclear energy to generate heat, which most frequently is then used in stream turbines to produce electricity in a nuclear power plant. Nuclear power can be obtained from nuclear fission, nuclear decay and nuclear fusion reactions. Presently, the vast majority of electricity from nuclear power is produced by nuclear fission of uranium and plutonium. Nuclear decay processes are used in niche applications such as radioisotope thermoelectric generators. Generating electricity from fusion power remains at the focus of international research. This article mostly deals with nuclear fission power for electricity generation. Nuclear power has one of the lowest levels of fatalities per unit of energy generated compared to other energy sources. Coal, petroleum, natural gas and hydroelectricity each have caused more fatalities per unit of energy due to air pollution and accidents. Since its commercialization in the 1970 s, nuclear power has prevented about 1.84 million air pollution related deaths and the emission of about 64 billion tonnes of carbon dioxide equivalent that would have otherwise resulted from the burning of fossil fuels. 


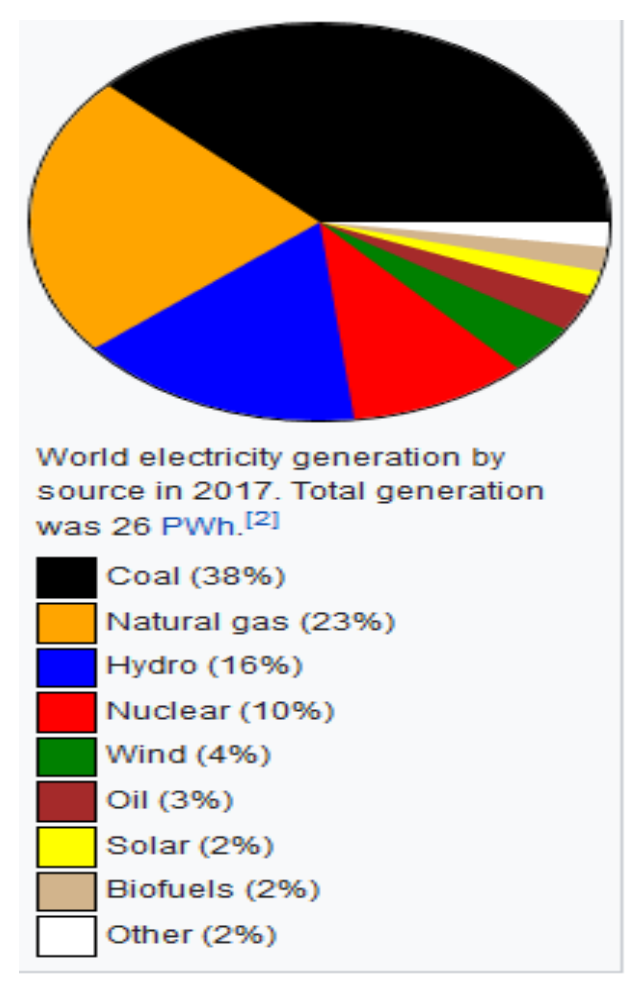

Fig: 3.10

From the above diagram it is clear that, most dominant world electricity generation source is coal it is $38 \%$ and next natural gas $23 \%$ then nuclear energy is $10 \%$. It is means that non-renewable resources are most dominant electricity generating source. Most dominant renewable source is hydro energy it is $16 \%$ others are wind energy $4 \%$ solar and biofuel both are $2 \%$.

\section{Electricity sector in India}

India is the world's third largest producer and third largest consumer of electricity. The power sector in India is mainly governed by the Ministry of Power. There are three major pillars of power sector these are Generation, Transmission, and Distribution. As far as generation is concerned it is mainly divided into three sectors these are Central Sector, State Sector, and Private Sector. The Ministry of Power is an Indian government ministry. The current Union Minister of State (Independent charge) is Raj Kumar Singh. The ministry is charged with overseeing electricity production and infrastructure development, including generation, transmission, and delivery, as well as maintenance projects. India faces challenges in electrical supply and delivery, and is often unable to meet demand, even in very large cities. The ministry acts as a liaison between the central government and state electricity operations, as well as with the private sector. The ministry also oversees rural electrification projects. The Ministry of Power is the apex body responsible for the development of electrical energy in India. This ministry started functioning independently from 2 July 1992 earlier, it was known as the Ministry of Energy. 


\section{Electricity generation in India}

India is the world's third largest producer of electricity. India's electricity production year by year increased. Fig:3.2 shows the India's electricity production is in third position.

\section{China}

US

India

Russia

Japan

Germany

Canada

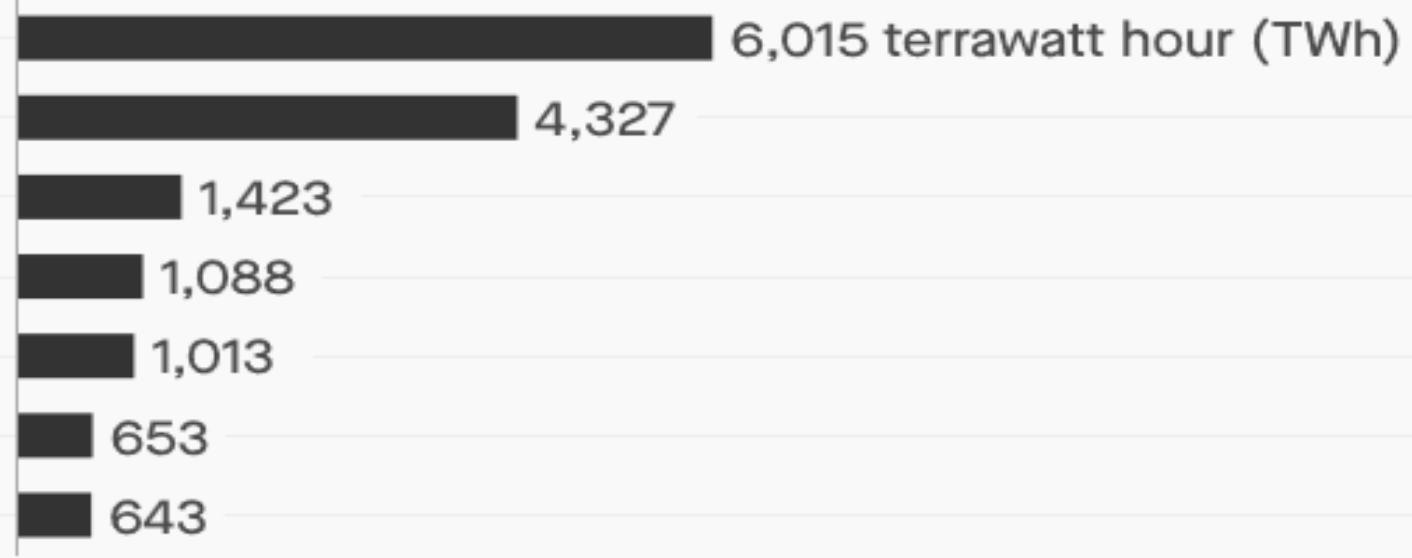

Source: secondary data fig: $\mathbf{3 . 1 1}$

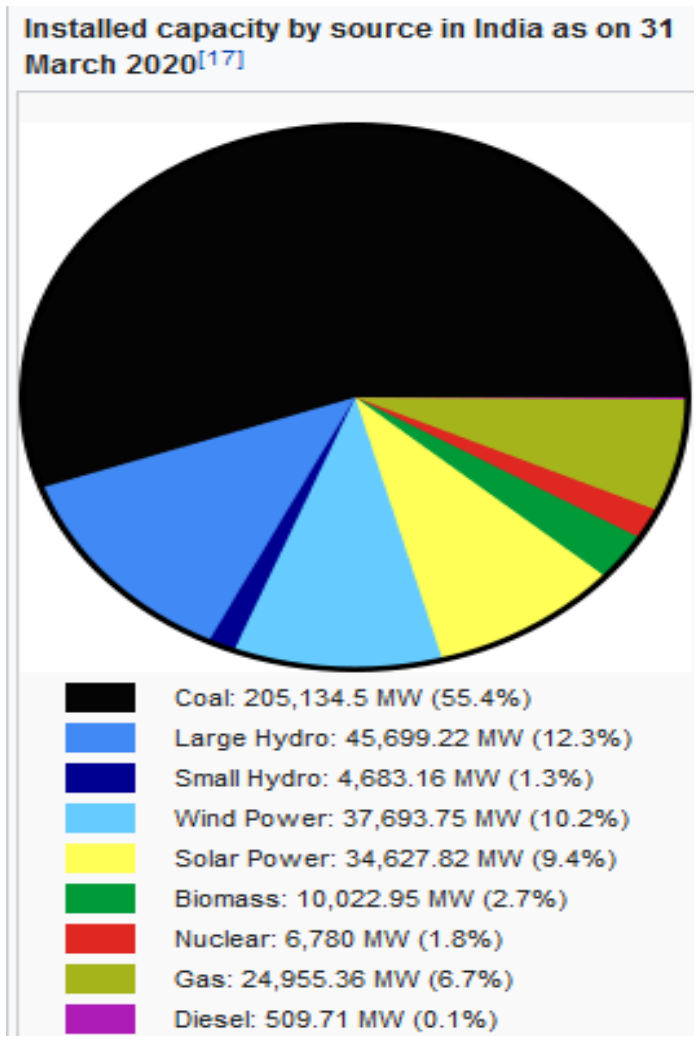

source :secondary data fig: $\mathbf{3 . 1 2}$ 
In fig:3.3 India's electricity sector is dominated by fossil fuels, in particular coal, which during the 2019-20 fiscal year produced about three-quarters of the country's electricity. The government is making efforts to increase investment in renewable energy. In 2020 most dominated source is coal $55.4 \%$.

Table: 1

\begin{tabular}{|c|c|c|c|c|c|c|c|c|c|c|}
\hline \multirow[b]{2}{*}{ Sector } & \multicolumn{5}{|c|}{ Thermal (MW) } & \multirow{2}{*}{$\begin{array}{c}\text { Nuclear } \\
\text { (MW) }\end{array}$} & \multicolumn{2}{|c|}{ Renewable (MW) } & \multirow[b]{2}{*}{ Total (MW) } & \multirow[b]{2}{*}{$\%$} \\
\hline & Coal & Lignite & Gas & Diesel & $\begin{array}{l}\text { Sub-Total } \\
\text { Thermal }\end{array}$ & & Hydro & $\begin{array}{c}\text { Other } \\
\text { Renewable }\end{array}$ & & \\
\hline State & $64,736.50$ & $1,290.00$ & $7,118.71$ & 363.93 & $73,509.13$ & 0.00 & $26,958.50$ & $2,349.98$ & $102,817.61$ & 29 \\
\hline Central & $56,340.00$ & $3,140.00$ & $7,237.91$ & 0.00 & $66,717.91$ & $6,780.00$ & $15,046.72$ & $1,632.30$ & $90,176.93$ & 25 \\
\hline Private & $74,733.00$ & $1,830.00$ & $10,580.60$ & 273.70 & $87,417.30$ & 0.00 & $3,394.00$ & $76,650.52$ & $167,461.82$ & 46 \\
\hline All India & $195,809.50$ & $6,260.00$ & $24,937.22$ & 637.63 & $227,644.34$ & $6,780.00$ & $45,399.22$ & $80,632.80$ & $360,456.37$ & 100 \\
\hline
\end{tabular}

\section{Source: secondary data}

In table: 3.1 The total installed capacity stated is after subtracting retired capacity (if any). Nearly 40,000 MW is in various stages of construction as on 31 March 2019. This table explains the state level central level private level and all India level installed capacity. This table shows the private level is more produced $46 \%$ produce less central level $25 \%$.

\section{Electricity consumption in India}

Indian is the world's third largest consumer of electricity. India's electricity consumption increased year by year.

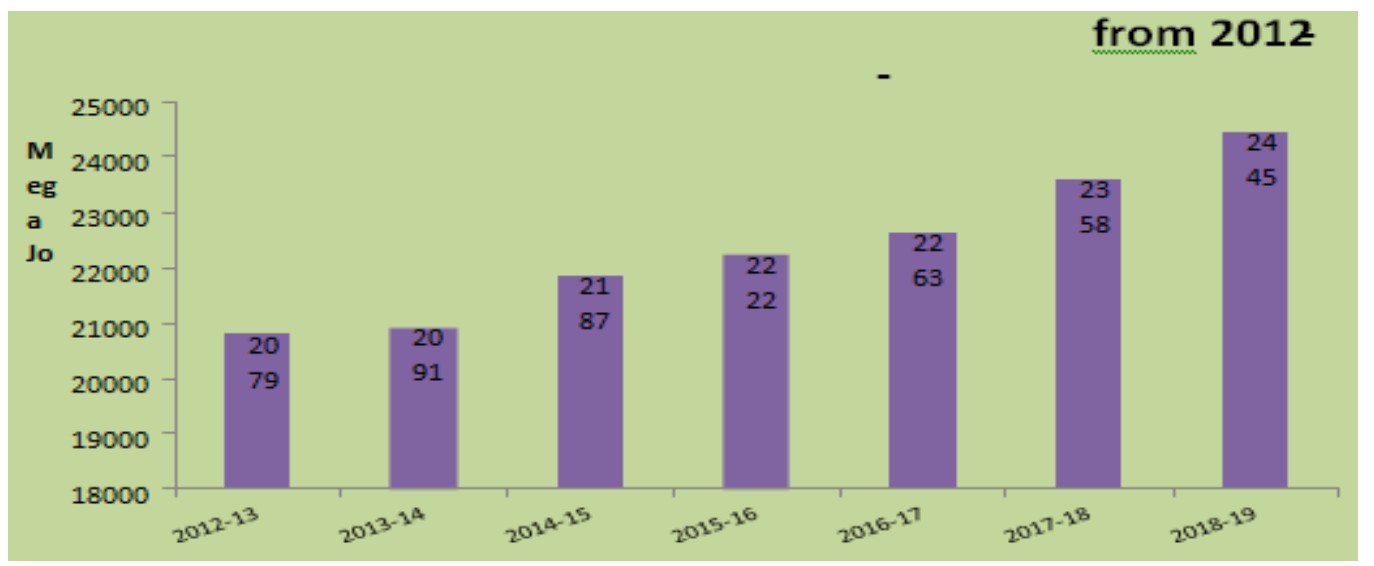

Source: secondary data

fig: 3.13 
Here fig: 3.4 shows that every year consumption is steadily increased. 2012 to 2019 it is $4 \%$ of increased. 2012 it is 20790 mega joule it is in 2019, 24453mega joule.

\section{Consumption of electricity by sectors}

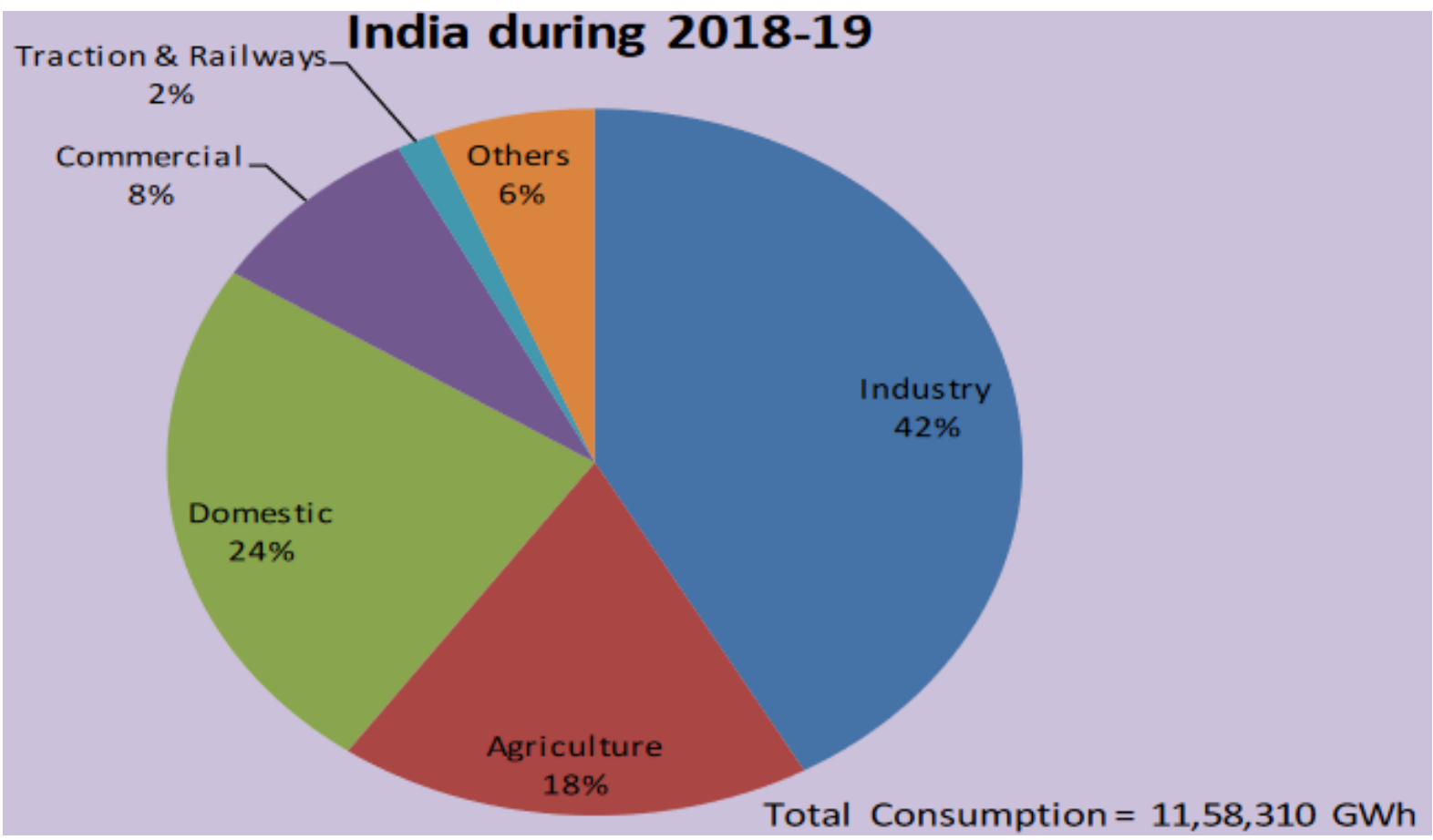

Source: secondary data

fig: 3.14

Consumption of electricity by sectors during 2018-19, industrial sectors is more used to electricity it is $42 \%$ next is domestic sector $24 \%$. Traction and railways are used only $2 \%$.

\section{Consumption pattern of household}

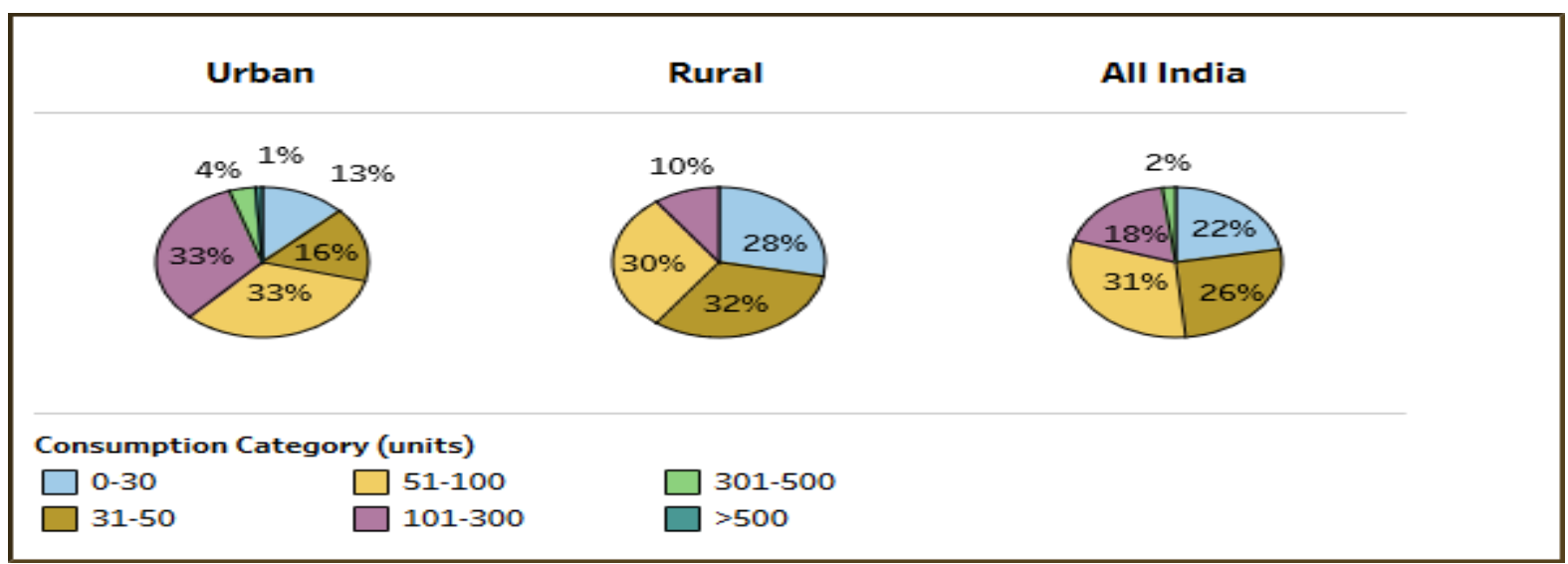

Source: secondary data

fig: $\mathbf{3 . 1 5}$ 
International Journal of Social Science and Economic Research

ISSN: 2455-8834

Volume:06, Issue:07 "July 2021"

In urban areas 30 to 500 units used only 1\% used 500 above. 51-100 units and 101-300 units more. Both are 33\%. Urban areas only 4\% used 301-500. In rural areas 32\% of people used 3150 units, 0-30 units used 28\%, 51-100 units used 30\%. In rural areas only 10\% used 101-300 and no one use 300 above units in rural areas. In all India level only $2 \%$ used 301-500. It means that India's most people are only used 300 below units.

\section{Problems in Indian power sector}

- Unequal electricity distribution

- Inadequate last mile connectivity

- Erratic power pricing

- Lack of adequate coal supply

- Lack of timely information on load and demand

- Poor infrastructure

- Theft of electricity

- Transmission, distribution and consumption problems

- Resistance of hydroelectric power projects

- Resistance of nuclear power generation

\section{Electricity sector in Kerala}

Kerala State Electricity Board Ltd (KSEB Ltd) is a public sector undertaking under the government of Kerala, India that generates, transmits and distributes the electricity supply in the state. The Kerala State Electricity Board, constituted by the Government of Kerala, by order dated 7.3.1957, under the Electricity (Supply) Act, 1948 is in the business of Generation, Transmission and Distribution of electricity and striving to provide quality electricity at affordable cost to all classes of consumers in the state of Kerala. As per section 172 (a) of the Electricity Act 2003 and as mutually decided by the Government of India and Government of Kerala, KSEB has continued as Transmission utility and Distribution licensee till 24-09-2008.

\section{Electricity generation in Kerala}

Kerala generates power from four sources - hydro power, thermal power, wind power and solar power. Of these, hydro and thermal power generations account for the considerable majority whereas wind and solar power generations make only marginal additions. Monsoon is essential to sustain the hydropower base in the State and the shortage in rainfall usually creates a power crisis. Yet hydro energy is the most reliable and dependable source of energy in Kerala. In addition to these considerations, hydro is also not a source of greenhouse gas emissions and is effectively a renewable energy source, even if this is not fully reflected in the official classification of what renewables sources are. KSEBL as on March 31, 2018 owns 37 
hydroelectric generating stations, 2 thermal power plants, 1 wind farm at Kanjikode, and 14.71 MW of solar plants at various locations with a total installed capacity of 2,232.46 MW. Perunthenaruvi small hydroelectric project of $6 \mathrm{MW}$ was added to system on October 24, 2017.

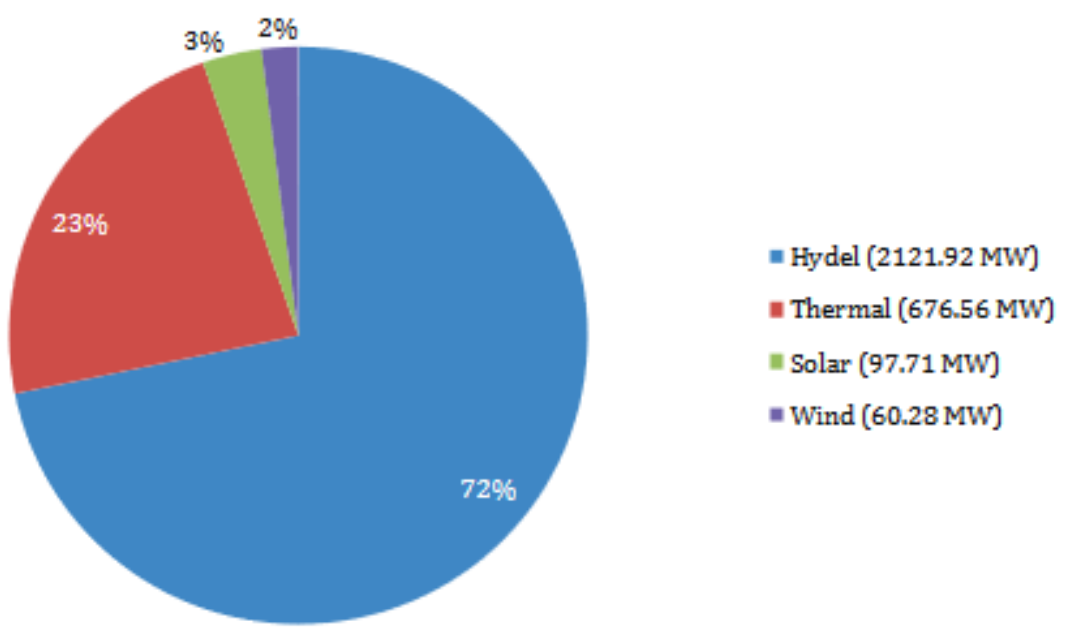

Source; secondary data

fig: 3.16

Total installed capacity of power in the State as on March 2018 is 2,956.47 MW. Of which, hydro power contributed the major share of 2,121.92 MW (71.77 per cent); while 676.56 MW was contributed by thermal projects (22.88 per cent), $60.28 \mathrm{MW}$ from wind (2.04 per cent) and 97.71 MW (3.30 per cent) from solar. Fig: 3.7 highlights the total installed capacity of Kerala from hydro, thermal and renewable sources.

\section{Electricity consumption in Kerala}

\section{Consumption in sector based}

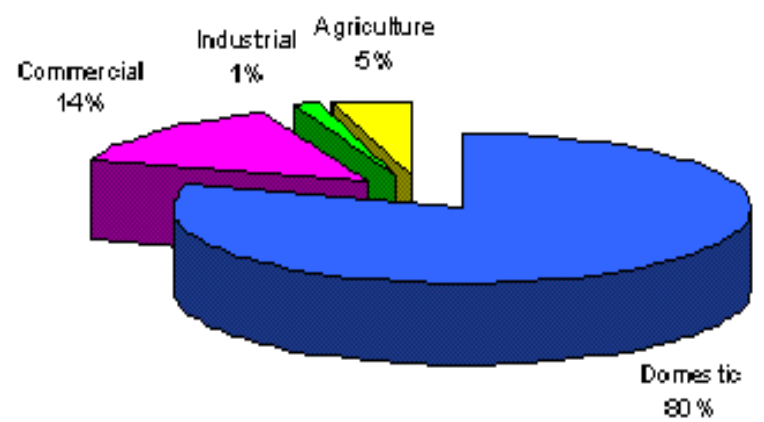


International Journal of Social Science and Economic Research

ISSN: 2455-8834

Volume:06, Issue:07 "July 2021"

Fig: 3.8 shows that domestic consumers are more used. $80 \%$ of electricity is used the domestic consumers. Next commercial sectors they use $14 \%$ of electricity. Agriculture sector use $5 \%$ and $1 \%$ use the industrial sector

\section{Consumption in domestic level}

Domestic consumer's form 77.89 per cent of total consumers, consumes 50.36 per cent of the total energy and provide 35.80 per cent revenue to KSEBL. The pattern of total consumption of electricity in Kerala has been fluctuating over the years

\begin{tabular}{|c|r|r|}
\hline Year & Total Consumption of \\
Electricity (MU) & Growth Rate (\%) \\
\hline $2012-13$ & 16,838 & 5.37 \\
\hline $2013-14$ & 17,454 & 3.66 \\
\hline $2014-15$ & 18,426 & 5.57 \\
\hline $2015-16$ & 19,325 & 4.88 \\
\hline $2016-17$ & 20,453 & 5.84 \\
\hline $2017-18$ & 21,159 & 3.45 \\
\hline
\end{tabular}

Source; secondary data

table: 2

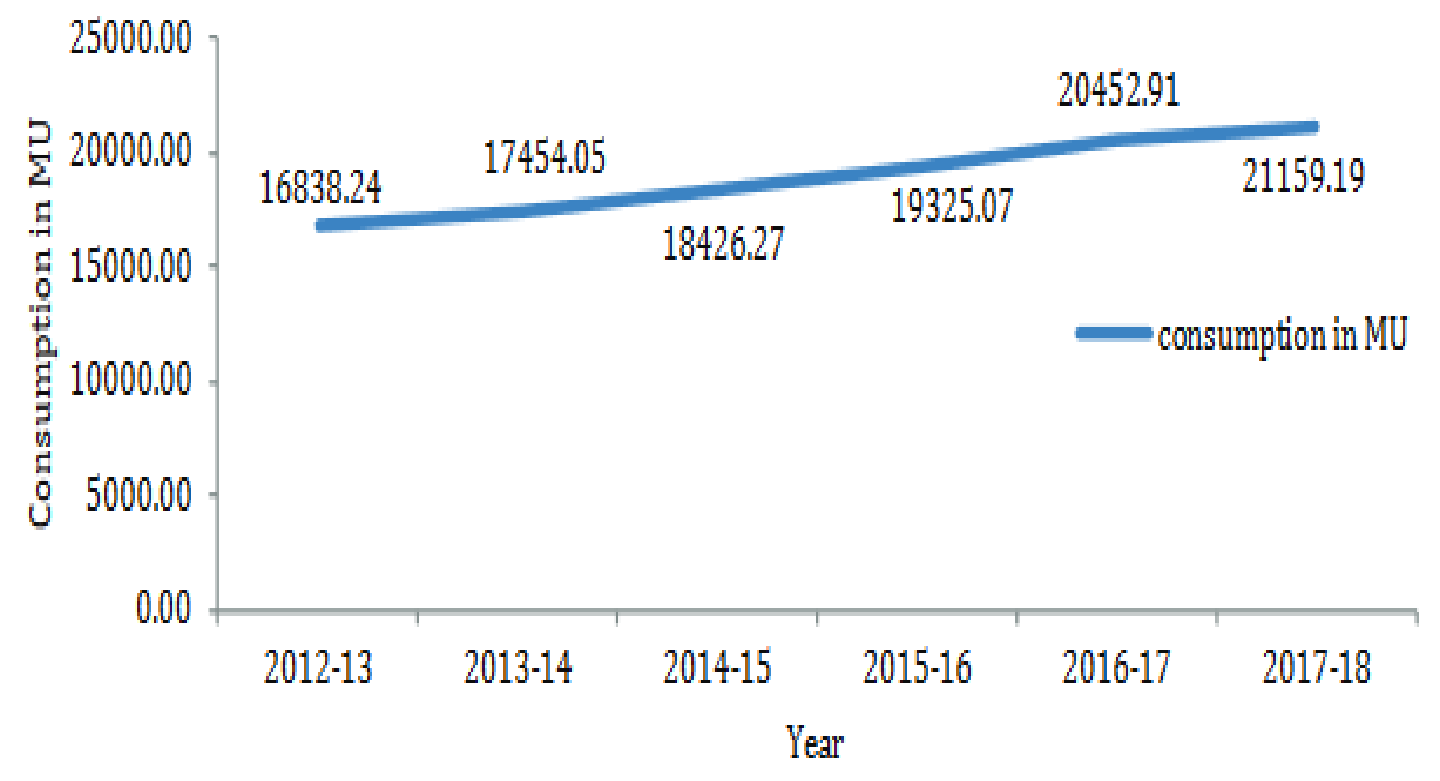

Source: secondary data

fig: 3.18 
International Journal of Social Science and Economic Research

ISSN: 2455-8834

Volume:06, Issue:07 "July 2021"

In Kerala, electrical energy consumption has increased to 21,159 MU in 2017-18 from 20,453 MU in 2016-17, an increase of 3.45 per cent. Every year consumption steadily increased between $3-6 \%$.

\section{TRENDS IN THE PRICE OF ELECRICITY}

Electricity sector is the most critical components of an infrastructure that aspects India's economic growth and the utility electricity sector in India has one National Grid with an installed capacity of $344.69 \mathrm{GW}$ as on 31 August 2018. Renewable power plants constituted $33.60 \%$ of total installed capacity. During the scale year 2017-18, the gross electricity generated by utilities in India was 1,303.49.

In India The Electricity Act of 2003, The National Electricity Policy, 2005, and The Tariff policy, 2006 provide the structure and principle to be followed for the determination of electricity tariff. Despite considerable progress in the implementation of the Electricity Act and associated policies over the past decade, most distribution companies continue to post significant losses. One of the main reasons for losses is the expense of providing below cost power to key consumer groups such as agricultural and domestic consumers.

\section{FACTORS AFFECTING THE PRICE OF ELECTRICITY}

Electricity prices generally reflect the cost to build, finance, maintenance, manage, and operate power plants and the electricity grid (the complex system of power transmission and distribution lines), and to operate and administer the utilities that supply electricity to consumers. Electricity prices are dynamic so they can change depending on the demand and other factors.

\section{Demand and supply}

Electricity prices are dynamic so they can change depending on the demand and supply of electricity. Energy from nuclear. Coal, gas, oil, and renewable sources reacts quickly in response to the available supply. Thus supply is a key contributing factor to price fluctuations, which can occur on an hourly basis. Similarly, demand for heating, cooling, light, and processes varies in response to demand in terms of economic, technological, and efficiency measures.

\section{Fuels}

Fuel costs can vary, especially during periods of high demand. High electricity demand can increase demand for fuel, such as natural gas, which can result in higher prices for the fuel and, in turn, higher costs to generate electricity.

\section{Power generating capacity and availability}


Power generating capacity and availability are depends on the supply and demand. In regions where are more than two power companies, prices tend to be lower than usual because the supply is higher.

\section{Cost incurred by the power plants}

Each power plant has construction, maintenance, and operating costs. Higher the cost incurred by the power plants greater will be the electricity price.

\section{Weather condition}

Rain and snow provide water for low-cost hydropower generation. Wind can provide low-cost electricity generation from wind turbines when wind speeds are favourable. However, extreme temperatures can increase the demand for electricity, especially for cooling, and demand can drive prices up.

\section{Government regulation}

In some states, prices are fully regulated by Public Service Commissions, while in others there is a combination of unregulated prices (for generators) and regulated prices (for transmission and distribution).

\section{Transmission and distribution system}

The electricity transmission and distribution systems that deliver electricity have maintenance costs, which include repairing damage to the systems from accidents for extreme weather conditions.

\section{Financial speculation}

Energy prices can be an elected significantly speculation. Which is the least transparent factor of all. If a market doesn't seem to be following the direction indicated by supply or demand-related factors, the cause is almost always financial speculation, which is largely invisible and causes unexpected movements.

\section{Effect of COVID-19 on Indian energy consumption}

The COVID-19 pandemic has forced governments around the world to impose tough restrictions on daily life to prevent the spread of the virus. With these restrictions, roads and airports are nearly empty, shops and restaurants are closed, and industrial activities are largely at a halt worldwide. As strict lockdown was imposed all over India from 25 March 2020 to May 2020, a significant decline in power demand was seen, a nearly $20 \%$ to $40 \%$ drop. 


\section{Power supply and generation}

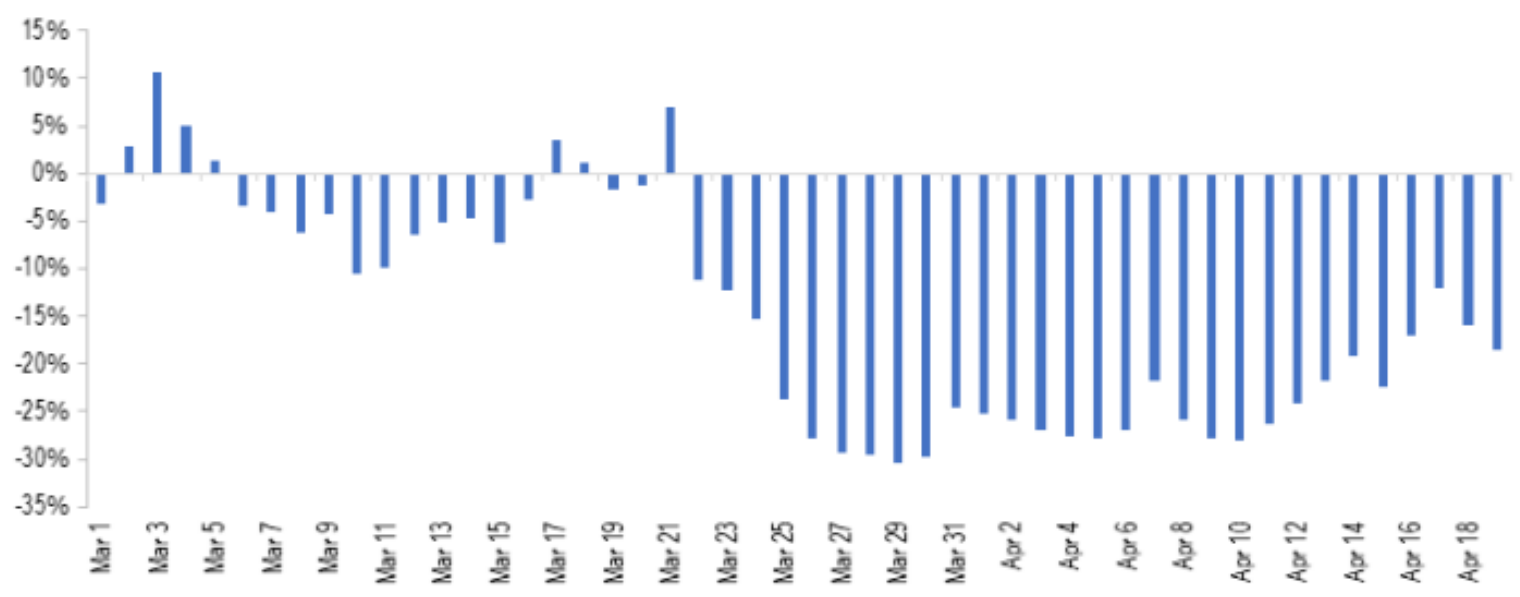

\section{Source; secondary data fig: $\mathbf{3 . 1 9}$}

As electricity cannot be stored in large amount, the power generation and supply for a given day are planned based on the forecast for demand. The months of January and February in 2020 had seen an increase of 3\% and 7\% in power supply, respectively as compared to 2019 (year-onyear). In comparison, the power supply saw a decrease of 3\% between March 1 and March 24. During the lockdown between March 24 and April 19, the total power supply saw a decrease of about $25 \%$ (year-on-year).

\section{Electricity consumption}

The Government of India ordered a nationwide lockdown for 3 weeks from 25th March, 2020 to control the spread of COVID-19. The lockdown has been extended a few times to date with gradual relaxation. It had a significant impact on the electricity demand due to reduction in commercial and industrial activities. The all India electricity consumption dropped by $22 \%$ in the first week of lockdown as compared to the peak of the previous week. In the initial lockdown period, the daily electricity consumption was $25-30 \%$ lower than its corresponding value in 2019. The residential electricity consumption, on the other hand, is expected to have increased during the lockdown as people spent more time at home. 


\section{All India electricity consumption}

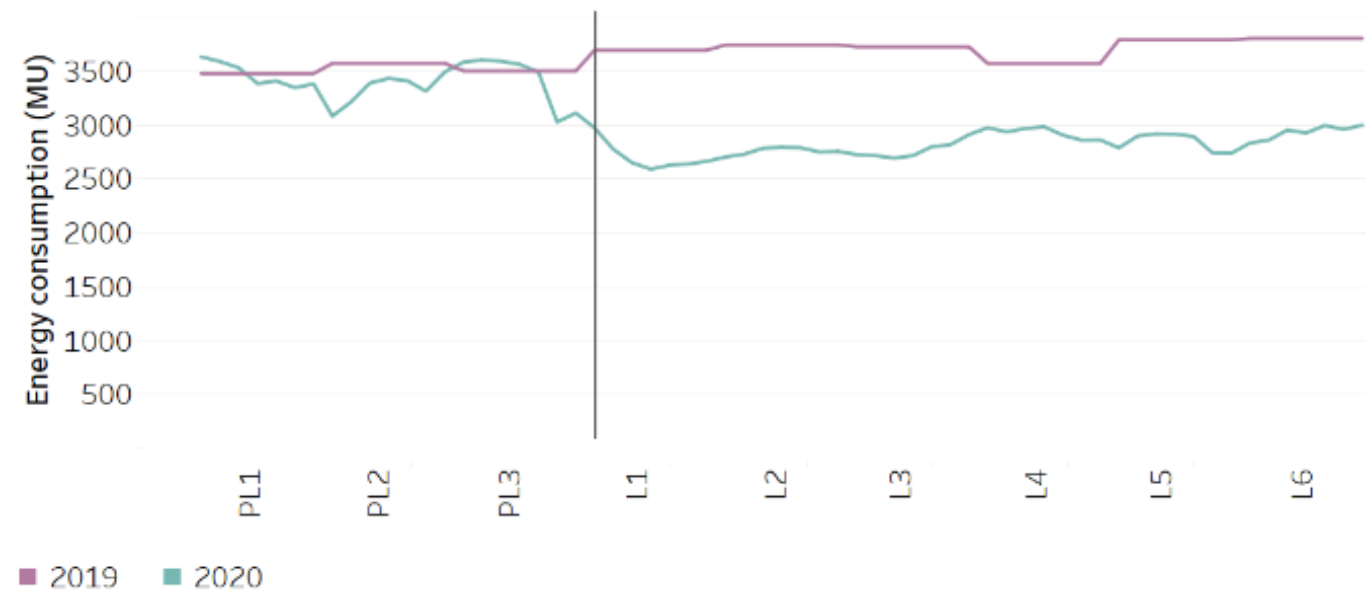

PL1 to PL3 are pre-lockdown weeks 1 to 3 and L1 to L6 are lockdown weeks 1 to 6.

\section{Source; secondary data fig; $\mathbf{3 . 2 0}$}

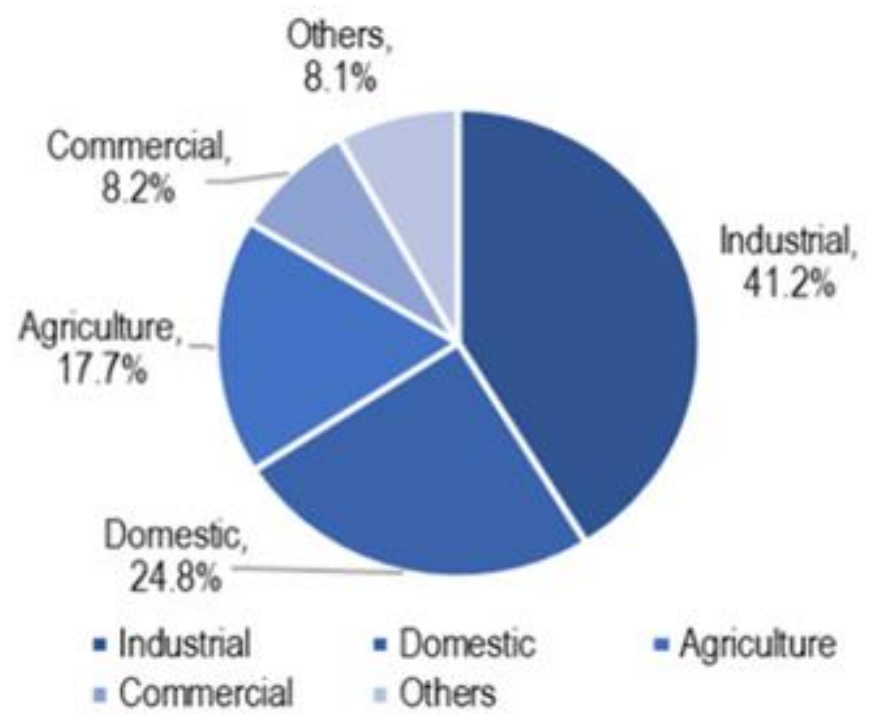

Source: secondary data

fig: 3.21

If we look at the consumption pattern by consumer category, in 2018-19 41\% of total electricity consumption was for industrial purposes, followed by $25 \%$ for domestic and $18 \%$ for agricultural purposes. As the lockdown has severely reduced the industrial and commercial activities in the country, these segments would have seen a considerable decline in demand for electricity. 


\section{Domestic consumption}

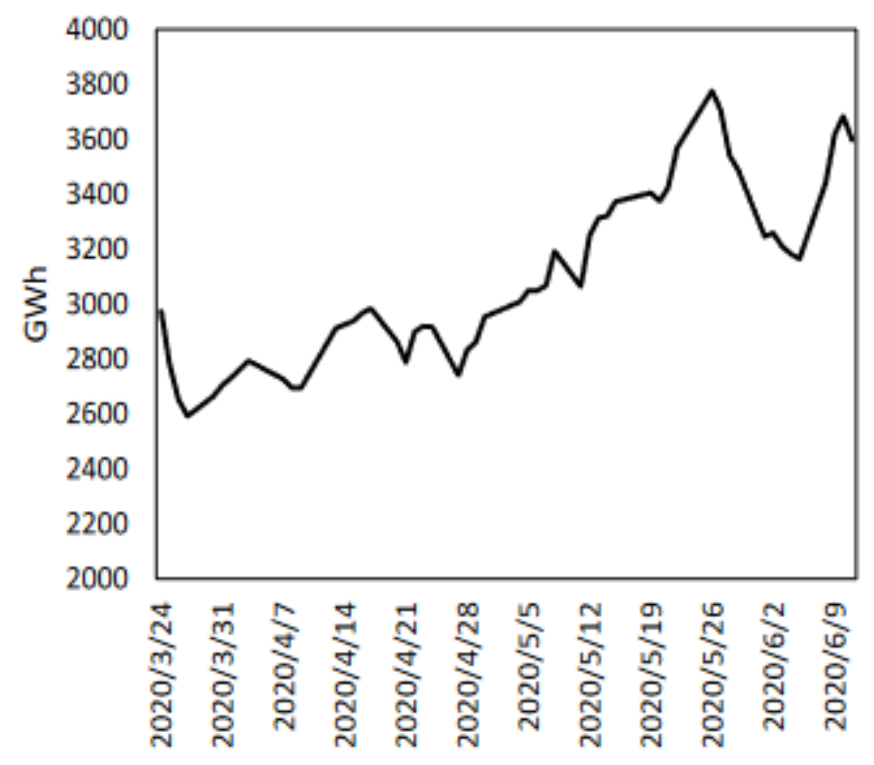

Source: secondary data fig. $\mathbf{3 . 2 2}$

The daily average electricity consumption of all the sample households was $26 \%$ higher in the lockdown period as compared to the pre-lockdown period. Much of the population is working from home and schools have closed, meaning home computers and televisions are busier than ever. The highest peak is at lunchtime, when cooking is added to the power consumption of working from home. But overall, the country is actually using less energy because of businesses being closed. The National Grid reports that morning and afternoon electricity demand is down by nearly $20 \%$. But most of that is due to lower demand from large, industrial users like factories.

\section{Energy conservation and its importance}

Energy conservation is the effort made to reduce the consumption of energy by using less of an energy service. This can be achieved either by using energy more efficiently (using less energy for a constant service) or by reducing the amount of service used (for example, by driving less). Energy conservation is a part of the concept of Eco-sufficiency. Energy conservation reduces the need for energy services and can result in increased environmental quality, national security, personal financial security and higher savings. It is at the top of the sustainable energy hierarchy. It also lowers energy costs by preventing future resource depletion.

Energy can be conserved by reducing wastage and losses, improving efficiency through technological upgrades and improved operation and maintenance. On a global level energy use can also be reduced by the stabilization of population growth. 
Energy can only be transformed from one form to other, such as heat energy to motive power in cars, or kinetic energy of water flow to electricity in hydroelectric power plants. However machines are required to transform energy from one form to other. The wear and friction of the components of these machine while running cause losses of very high amounts of energy and very high related costs. It is possible to minimize these losses by adopting green engineering practices to improve life cycle of the components.

\section{INCOME OF THE HOUSEHOLD}

\section{NO: OF EMPLOYED PERSONS IN FAMILIES}

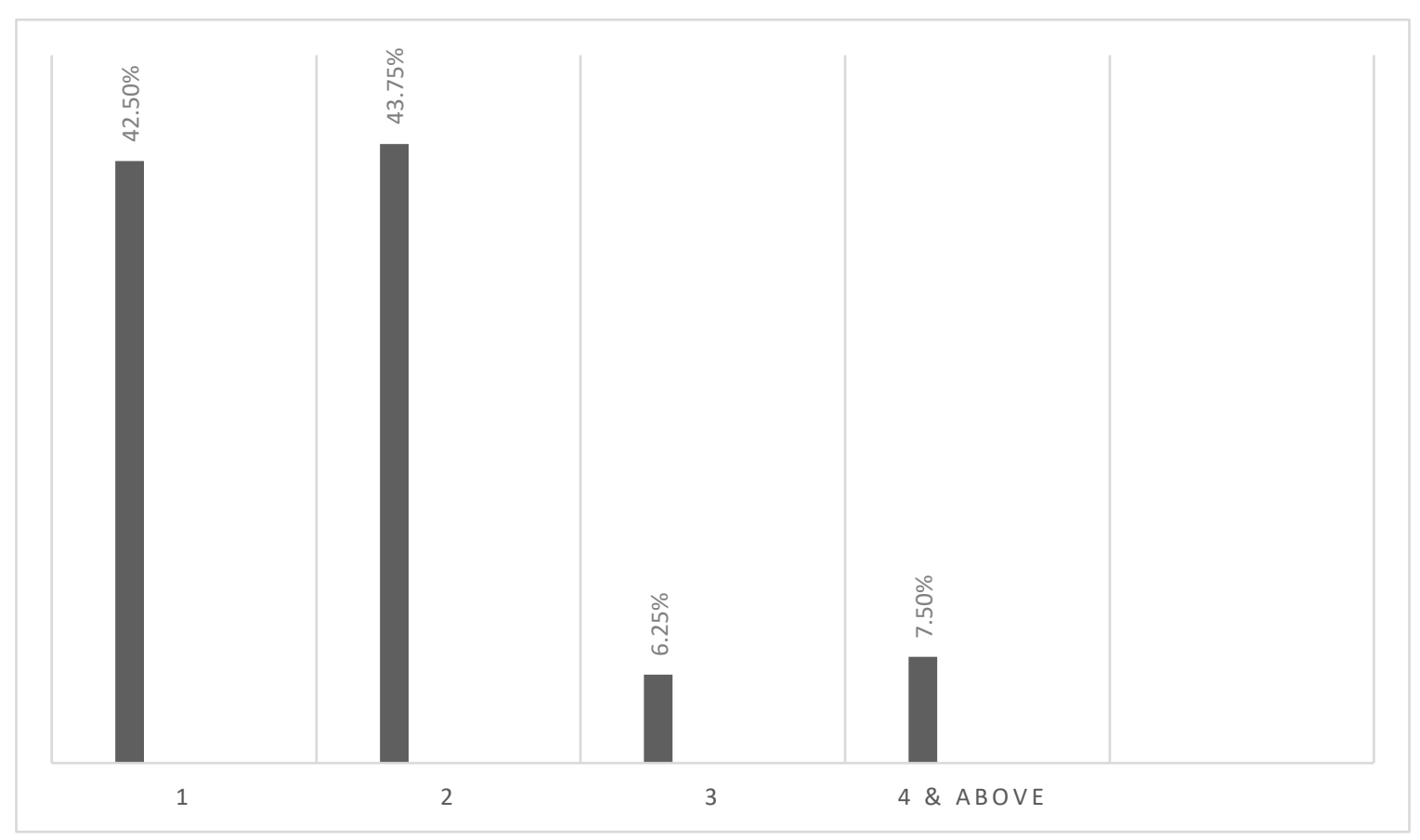

SOURCE : PRIMARY DATA

illustrates the number of employed person in families. There are 42.5 percent of family has only one employed person and 43.75 percent of families has two employed person and 6.25 percent of family has three employed persons and 7.50 percent of familes has four and above employed person. 


\section{CATEGORY OF EMPLOYMENT}

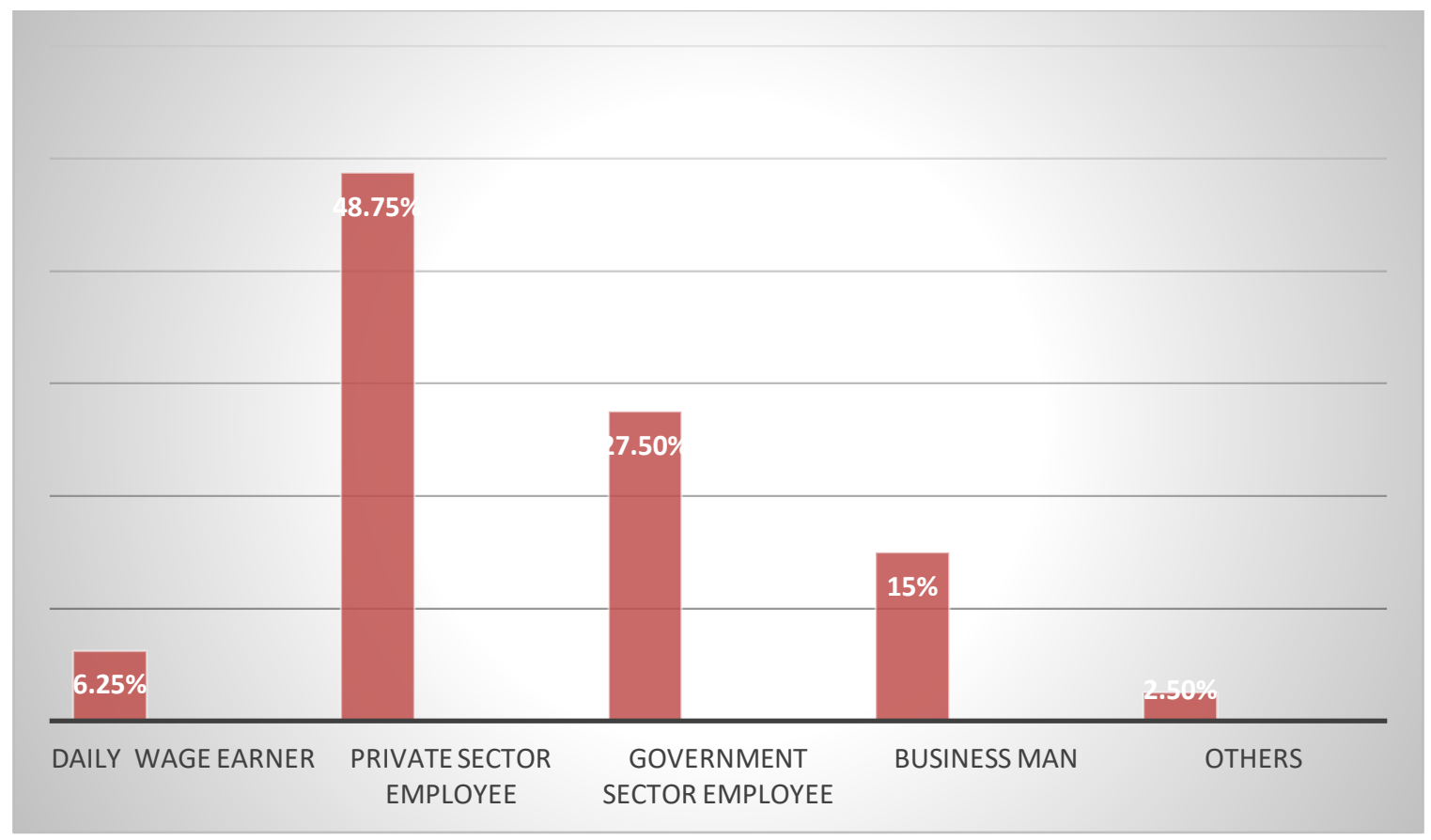

illustrates category of employment among the respondents. 6.25 percent of respondents are daily wagers and 48.75 are private sector employees and 27.50 percent are government employees and 15 percent of them are business and 2.50 respondents are categorized under others.

\section{MONTHLY INCOME}

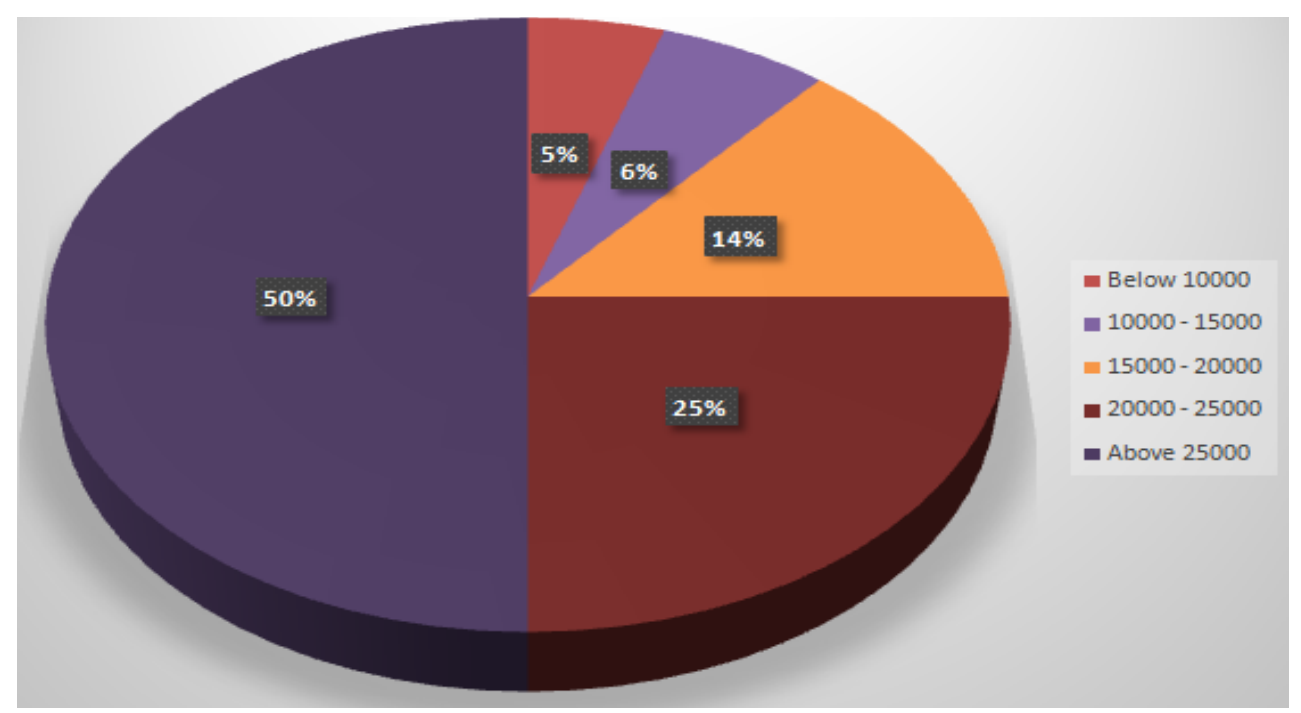

SOURCE : PRIMARY DATA 
represents the income of families. 50 percent of respondents have above 25000 monthly income. And 25 percent of them have 20000-25000 and 14 percent of respondents have 15000-20000 and 6 percent of them have 10000-15000 and 5 percent of respondents have below 10000

\section{CONSUMPTION AND EXPENDITURE PATTERN OF ELECTRICITY}

ELECTRONIC EQUIPMENTS OF THE HOUSEHOLD

\begin{tabular}{|l|l|l|l|}
\hline $\begin{array}{l}\text { SL } \\
\text { NO }\end{array}$ & $\begin{array}{l}\text { ELECTRONIC } \\
\text { EQUIPMENTS }\end{array}$ & $\begin{array}{l}\text { FREQUENCY ( OUT OF } \\
80)\end{array}$ & $\begin{array}{l}\text { PERCENTAGE } \\
\text { (OUT OF 100) }\end{array}$ \\
\hline 1 & Lighting (tube/bulb) & 80 & $100 \%$ \\
\hline 2 & Fan & 80 & $100 \%$ \\
\hline 3 & AC/Cooler & 20 & $25 \%$ \\
\hline 4 & Refrigerator & 77 & $96.25 \%$ \\
\hline 5 & Mixer Grinder & 79 & $98.75 \%$ \\
\hline 6 & Washing Machine & 51 & $63.75 \%$ \\
\hline 7 & Iron Box & 78 & $97.5 \%$ \\
\hline 8 & Induction Cooker & 37 & $46.25 \%$ \\
\hline 9 & Invertor & 19 & $23.75 \%$ \\
\hline 10 & Motor & 60 & $\mathbf{7 5 \%}$ \\
\hline 11 & Television & 80 & $100 \%$ \\
\hline 12 & Computer & 45 & $\mathbf{5 6 . 2 5 \%}$ \\
\hline 13 & $\begin{array}{l}\text { Chargers (lap top }, \text { mobile } \\
\text { phones etc.) }\end{array}$ & 80 & $100 \%$ \\
\hline 14 & Others & 35 & $43.75 \%$ \\
\hline
\end{tabular}




\section{CONSUMPTION OF ELECTRICITY UNITS ( BEFORE LOCKDOWN )}

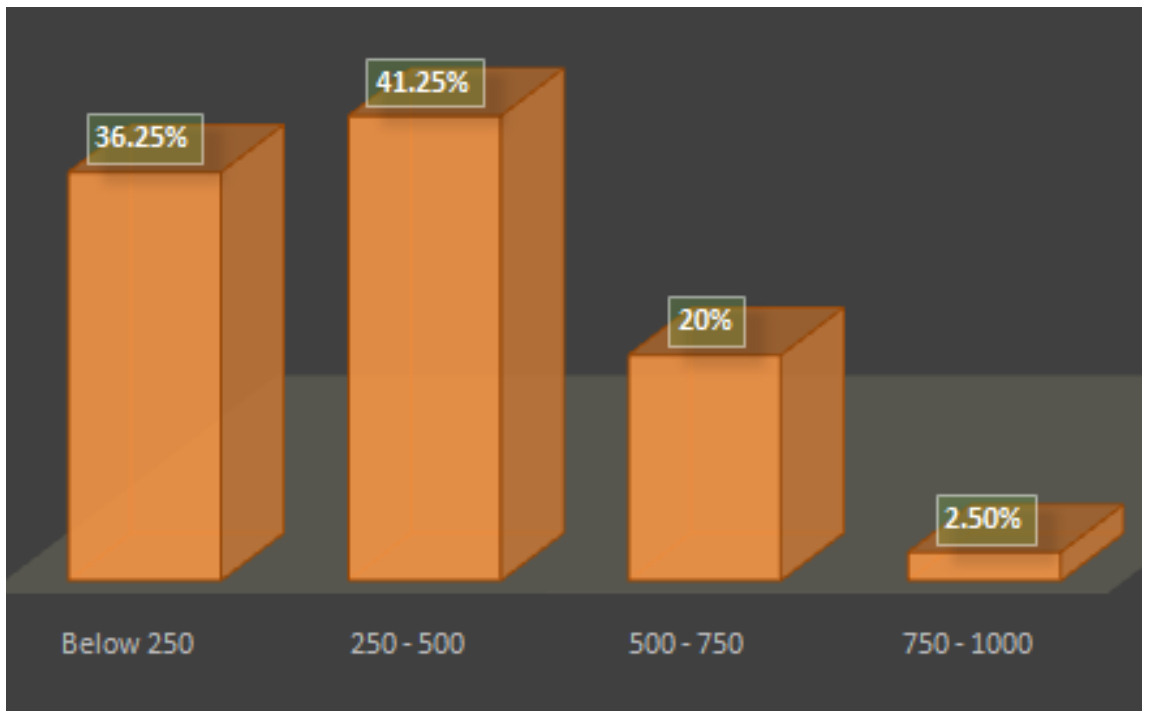

\section{SOURCE : PRIMARY DATA fig 4.8}

Fig 4.8 illustrates the consumption of electricity in unites before lockdown.

36.25 percent of respondents consumed below 250 unit electricity and 41.25 percent of respondents uses 250-500 units per month and 20 percent of respondents consumed 500-750 units of electricity and 2.50 percent of respondents uses 750-1000 units of electricity per month

\section{CONSUMPTION OF ELECTRICITY UNITS (AT THE TIME OF LOCKDOWN)}

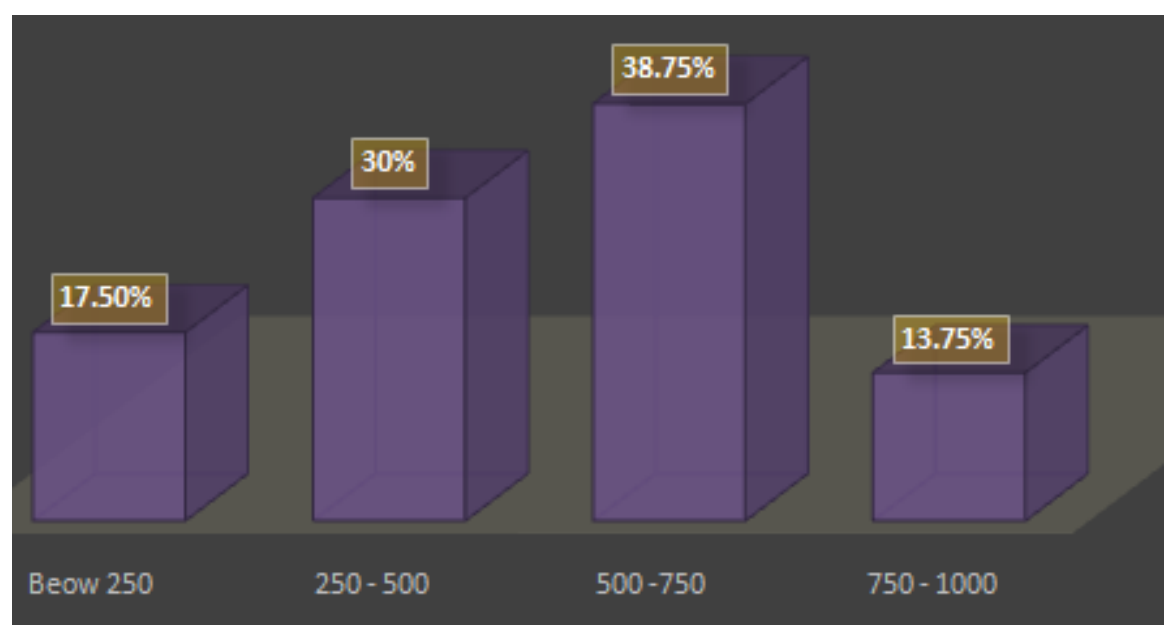

SOURCE : PRIMARY DATA fig 4.9 
Fig 4.9 illustrates the consumption of electricity in units at the time of lockdown. 17.50 percent says they consumed below 250 units and 30 percent of them used 250 to 500 units and 38.75 percent of them consumed 500 to 750 units and 13.75 percent of respondents used 750 to 1000 units of electricity at the time of lockdown.

\section{ELECTRICITY BILL OF THE HOUSEHOLD - BEFORE LOCKDOWN}

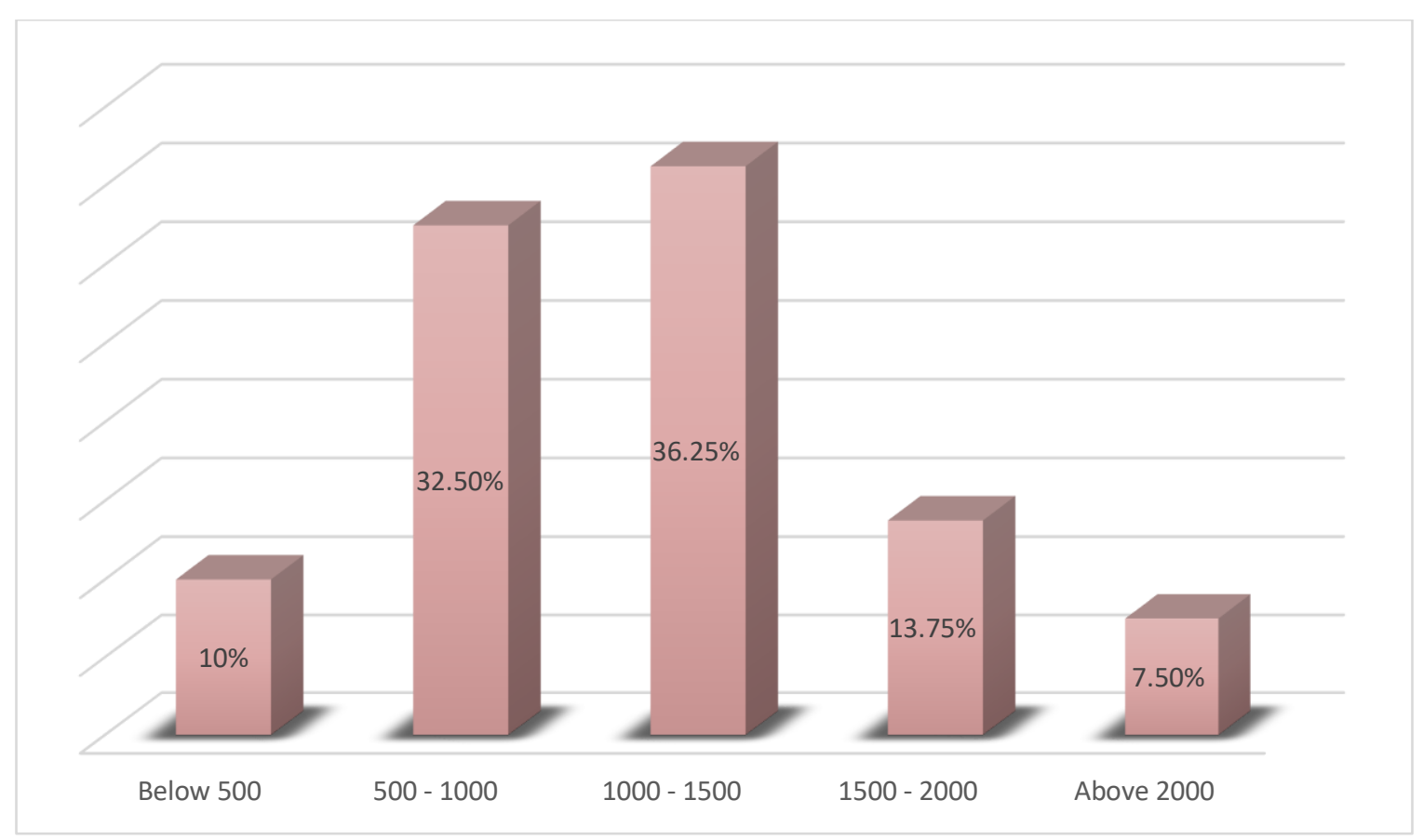

\section{SOURCE : PRIMARY DATA fig 4.10}

Fig 4.10 illustrates the electricity bill of the household before lockdown. 10 percent of respondents has get below 500 rupees and 32.50 percent of them get 500 to 1000 and 36.25 of them get 1000 to 1500 rupees bill and 13.75 percent of them get 1500 to 2000 rupees bill and 7.50 have above 2000 . 


\section{ELECTRICITY BILL OF THE HOUSEHOLD - AT THE TIME OF LOCKDOWN}

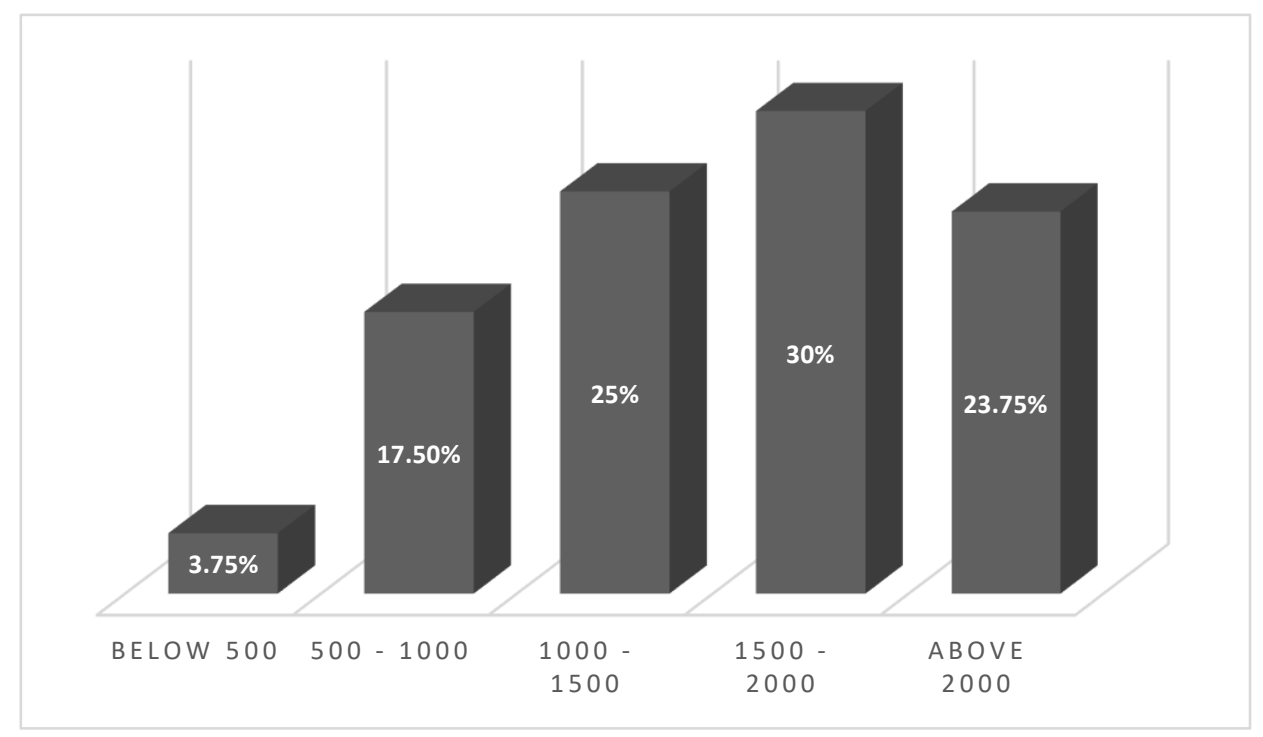

\section{SOURCE : PRIMARY DATA fig 4.11}

Fig 4.11 illustrates the electricity bill of the household at the time of lockdown. 3.75 percent of respondents has get below 500 rupees and 17.50 percent of them get 500 to 1000 and 25 of them get 1000 to 1500 rupees bill and 30 percent of them get 1500 to 2000 rupees bill and 23.75 have above 2000 .

\section{IF THERE IS ANY VARIATION BETWEEN THE ELECTRICITY BILL BEFORE LOCKDOWN AND AT THE TIME OF LOCKDOWN?}

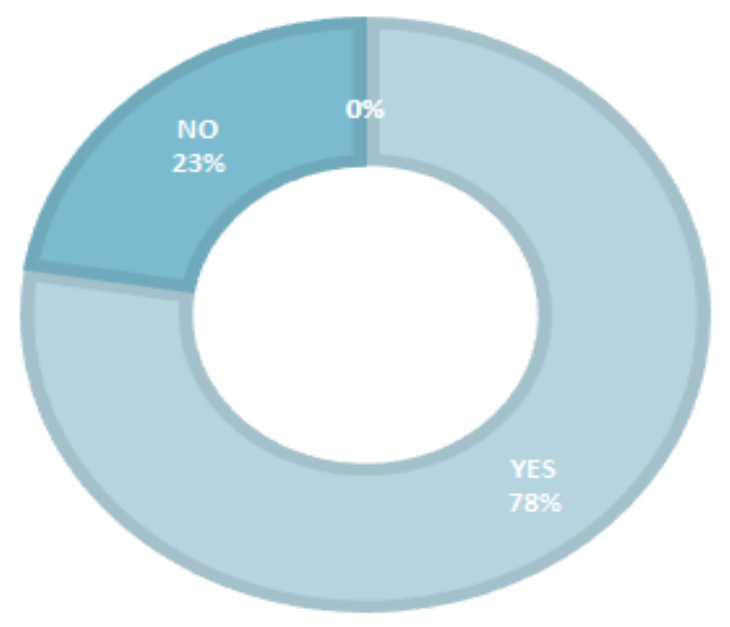

SOURCE : PRIMARY DATA fig 4.12 
Fig 4.12 represents the variation between the electricity bill before and at the time of lockdown. 77 percent of respondents says there is variation in electricity bill and 23 percent of them has no variation in the electricity bill.

\section{If yes - High, Low or No Variation}

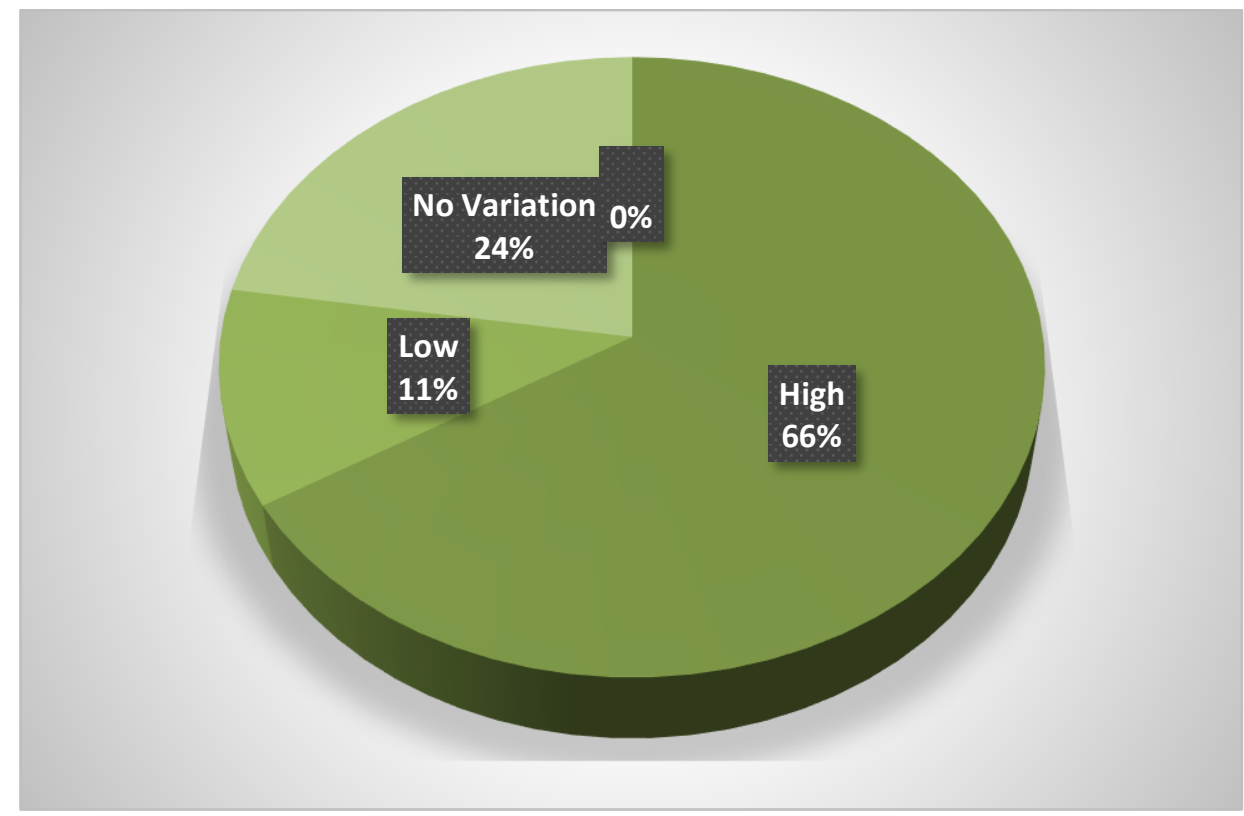

\section{SOURCE: PRIMARY DATA fig 4.13}

Illustrates the high, low and no variation in the electricity bill. 66 percent of respondents says there is high variation in the bill and 11 percent of them says low variation in the bill and 23 percent of respondents says there is no variation in the bill. 


\section{WHICH MEMBER OF YOUR FAMILY ALWAYS PAYS THE ELECTRICITY BILL OF YOUR HOUSEHOLD?}

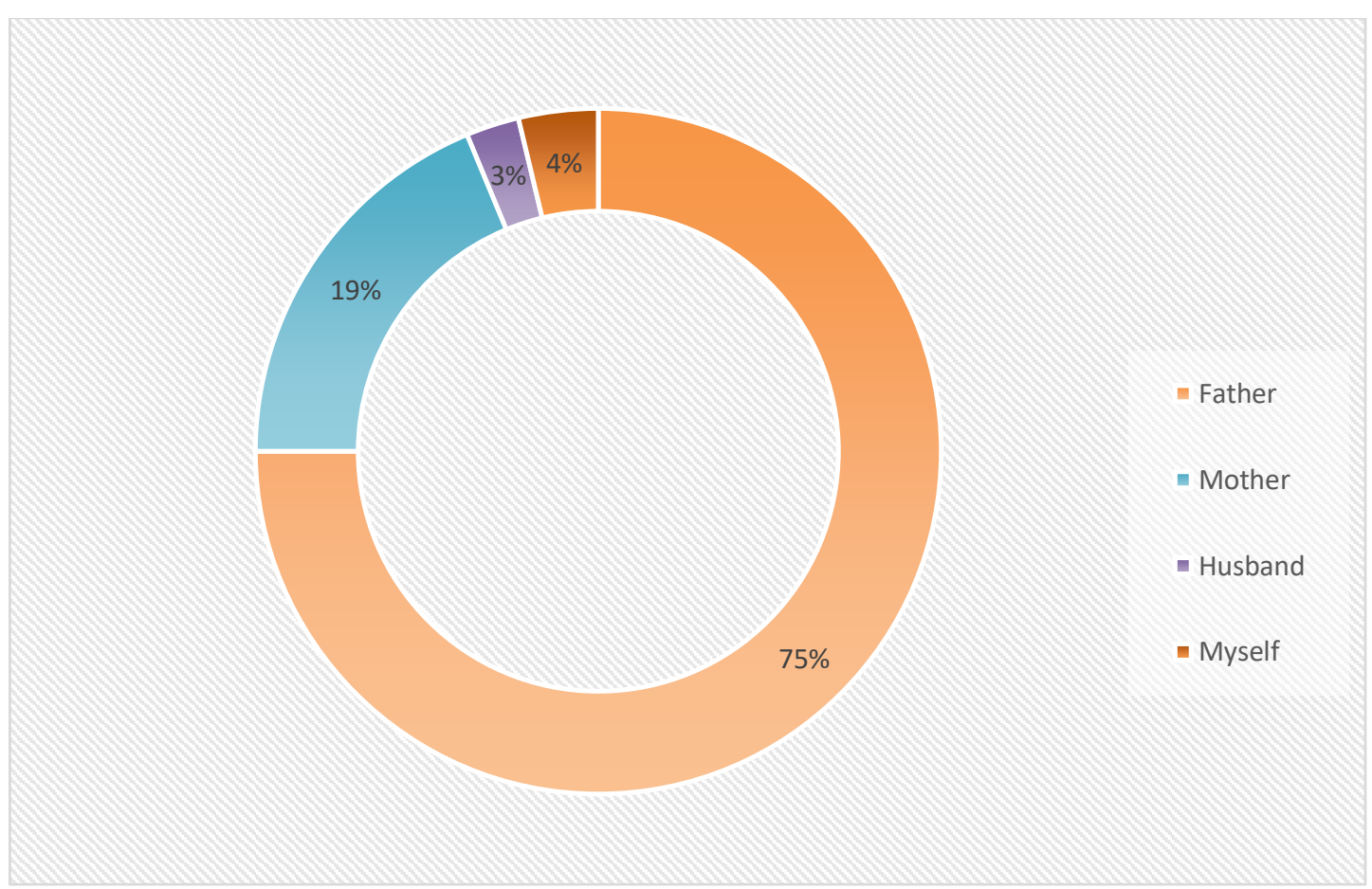

SOURCE: PRIMARY DATA fig 4.14

Fig 4.14 illustrates the person who pays the electricity bill. 75 percent of respondents says father pays the bill and 19 percent of them says mother pays the bill and 2 percent of them says husband pays the bill and other 4 percent of respondents says bill paid by themselves.

DO YOU SAVE ELECTRICITY?

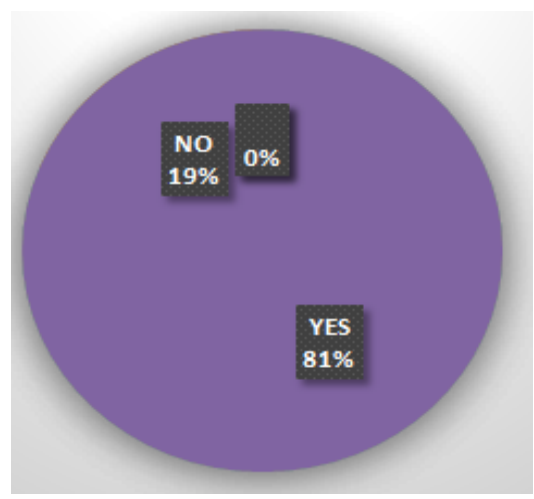

SOURCE : PRIMARY DATA fig 4.15 
Fig 4.15 illustrates saving electricity. 81 percent of respondents says they saves the electricity and 19 percent of respondents are not saving.

\section{DO YOU USE ANY ALTERNATIVE SOURCES OF ENERGY?}

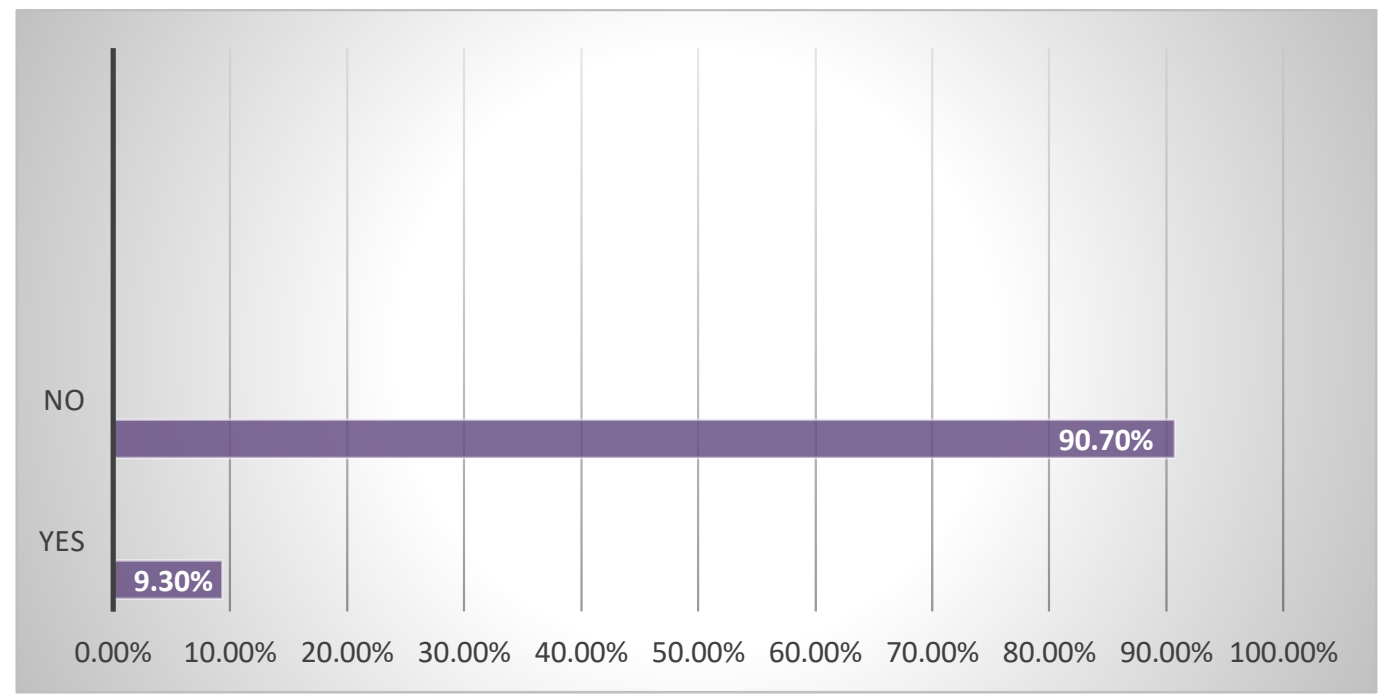

\section{SOURCE : PRIMARY DATA fig 4.16}

Fig 4.16 illustrates the alternative energy source. 90.70 percent of respondents does not have any other energy sources and other 9.30 percent of respondents are using other energy sources too.

\section{FINDINGS, SUGGESTIONS, CONCLUSION}

\section{FINDINGS}

- Majority of respondents are female

- Majority responds from nuclear family

- Majority responds from unmarried peoples

- In almost all the families, the head of the family is the father. Usually the head of the family handles the bill payments

- Majority of people depends on the private sector for employment. Half of the peoples income of 25000 and above

- It was found out that the people who have an average income of 25000 and above showed an increase in electricity consumption as they have more electricity equipment at their incomes

- Lighting, fan, television, charging equipment are there in all the household

- 50 percentage of the houses are equipped with refrigerator, mixer grinder, washing machine, computer, motor and iron box 
- Least number of equipment have like AC/cooler and inverter

- The electricity consumption rate of almost all families had an increase during lockdown

- There was increase in electricity consumption in almost all the houses during lockdown

- Majority of peoples save electricity

- Some people make use of other alternative sources like solar

\section{SUGGESIONS}

\section{For decrease electricity consumption}

- Turn off unnecessary lights.

- Use natural lights, heat and cooling

- Unplug unused electronics

- Use modern gadgets or appliances like CFL, motion sensor, energy star etc. for the less electricity consumption

- Use smart power strips

- Use alternative sources like solar

- Purchase energy efficient appliances

- Keep your appliances clean

- Turnoff electronic and appliances when they are not in use

- Unplug battery charges when not in use

- Adjust your thermostat according to the time of day

- Use ENERGY STAR qualified products

- Replace older home appliances with energy efficient models

- Select iron box with automatic temperature cutoff

- Do not iron wet cloths

- Do not open the door of the refrigerators frequently

- Always wash only with full load in washing machine

- Prefer natural dyer over electric dyer

- Prefer air conditioners having automatic temperature cutoff

- Keep regulators at low cool position

- Electronic stove- use flat bottom pans that make full contact with the cooking coil

- Do not switch on the power when TV and audio systems are not in use

- Don't miss use water

- Avoid over decoration with lighting and equipment

- Use always electricity minimal

From the government side 
International Journal of Social Science and Economic Research

ISSN: 2455-8834

Volume:06, Issue:07 "July 2021"

- Government promote people to use alternative source of energy like solar

- Enforce government buildings and street lights be powered by solar energy

- Introduce more effective management and information system

\section{CONCLUSION}

The electricity consumption has increased day by day. Most of the families in the Thiruvananthapuram Corporation are nuclear families. At least one member of the family is employed. More members of people work in private sectors and government sectors. Most of these houses have electric equipment like lighting, fans, refrigerator, mixer grinder, iron box, washing machine, motor, television, chargers etc. The usage of these equipment lead to the increase in electricity consumption. Most of the families have electric bill which goes beyond 1000. The least number of families use equipment like AC/cooler and inverter.

The lockdown has been declared because of the spread of COVID-19. This situation caused an increase in the consumption of electricity in every households. The amount of consumption was higher than the previous ones. So this is assumed that the amount of time people stay at their home make a huge impact on electricity consumption. During lockdown, the people were always at their homes, the new mode of learning for student and for the employees used much more electricity than the usual one. Now a days people save electricity. Because the increased amount of electricity bill force the people use electricity wisely.

\section{BIBLIOGRAPHY}

- Joy Drunkenly, Gunnar Knapp and Sandar Glatt (1981), a study on 'Factors affecting the consumption of energy using developing country'

- H. Craig Petersen (1982), a study on 'Electricity consumption in rural versus urban area'

- S.K.N Nair (2000), an article on ' Energy infrastructure in India: Assessing power sector needs

- Pradeep Chandravedi (2004), a study on 'Energy conservation in India'

- V.S Varma (2004), a study on 'Power reforms-overview of power sector'

- Anil Kakkodar (2004), a study on 'Fast breeding nuclear energy'

\section{WEBSITES}

- www.wikipedia.org

- www.kseb.in 
International Journal of Social Science and Economic Research

ISSN: 2455-8834

Volume:06, Issue:07 "July 2021"

- $\quad \underline{w w} . p w c . i n$

- $\quad \underline{w w}$. electricalindia.in

- $\quad$ www.thehindu.com

- $\quad$ www.kerala.gov.in 